\title{
AN HISTORICAL ARGUMENT FOR THE RIGHT TO COUNSEL DURING POLICE INTERROGATION
}

\section{INTRODUCTION}

Escobedo v. Illinois ${ }^{1}$ raises once more before the Supreme Court the problem of the right to counsel during police interrogation. The facts of the case are typical of several which have arisen during the past ten years. Danny Escobedo, a twenty-two year old man of Mexican extraction, was suspected of murdering his brother-in-law. The police brought Mr. Escobedo to the station and proceeded to interrogate him. When he asked to be allowed to speak to his attorney, the police refused. Later his attorney appeared at the station showing the desk sergeant the Illinois statute which requires that anyone held in custody be allowed to see his attorney "except in cases of imminent danger of escape."2 The attorney caught sight of Escobedo, warned him by sign to keep silent but was not allowed to speak to him. The interrogation lasted about three hours. During that period, Escobedo later claimed, the police attempted to incriminate his sister, confronted him with the charge by his accomplice that he had actually committed the crime, and promised him in Spanish that if he confessed, he would not be prosecuted. The police explicitly denied only the last claim. Finally Escobedo confessed. At trial his attorney objected to the introduction of the confession on two grounds, that it was involuntary, and that it was obtained after a denial of counsel. The trial judge, believing the police, ruled that the confession was voluntary. On appeal, ${ }^{3}$ the Supreme Court of Illinois affirmed the trial judge on the question

1. 84 Sup. Ct. 203 No. 320 (1963). Certiorari to the Supreme Court of Illinois which affirmed conviction sub nom., People v. Escobedo, 28 I1l. 2d 41, 190 N.E.2d 825 (1963). The case is annotated 52 IIL. BAR J. 602 (1964). The facts are summarized 190 N.E.2d at 826-27. Case docketed No. 615, 32 U.S.L. WeEk 3188 (U.S. Nov. 19, 1963).

2. Irr. Rev. Stats. ch. 38, § 477 (1957). The relevant text reads:

All public officers, sheriffs, coroners, jailers, constables or other officers or persons having the custody of any person committed, imprisoned or restrained of his liberty for any alleged cause whatever, shall, except in cases of immediate danger of escape, admit any practising attorney of law of this state, whom such person so restrained of his liberty may desire to see or consult, to see and consult such person so imprisoned, alone and in private, at the jail or other place of custody. . . .

3. In addition to the question of counsel and the question of the voluntariness of the confession Escobedo also asked that his conviction be reversed on the grounds that the trial judge had improperly excluded evidence of the effect on him of seeing his counsel turned away at the door of the police station, that the trial judge should have granted a directed verdict, and that the prosecutor had made inflammatory statements to the jury in his summation. Brief for Plaintiff in Error, pp. 3-6, People v. Escobedo, 28 Ill.2d 41, 190 N.E. $2 d 825$ (1963). The Illinois Supreme Court ignored these questions but reversed the conviction on the grounds of voluntariness. People v. Escobedo, No. 36707, Ill. Sup. Ct., January 14, 1963 (six justices for reversal, one dissent). Upon a motion for rehearing by the state, the court reconsidered the facts and handed down the reported opinion, supra. Especially stressed in the motion for rehearing were the fact that Escobedo had 
of voluntariness. Turning to the question of counsel, the court based affirmance on its observations that "the right of the police to interrogate suspects has never been seriously questioned," and that the presence of counsel at such interrogations " "would effectively preclude all interrogation - fair as well as unfair." "It is not necessary, the court said, for counsel to advise the accused of his rights during an interrogation; someone else can do that. In any case, it thought Escobedo a clever young man, fully aware of his rights; his attorney had advised him of his right to silence beforehand, he had refused to answer questions during previous questioning at the police station, and he even saw his attorney motioning him to silence. ${ }^{5}$ The court went on to construe the Illinois statute to mean that, though the police could not hold a man from his attorney at all times, they could at some. ${ }^{\circ}$

The constitutional question raised by this case is not new to the Supreme Court. In 1954 the Court considered it at length in the case of Crooker $v$. California. ${ }^{7}$ In Crooker a thirty-one year old college graduate with one year of law school training had confessed after twelve hours of police interrogation to murdering his paramour. He urged first that his confession was involuntary because the police refused him the access to counsel for which he had repeatedly asked and because the police had failed to bring him before a magistrate. Secondly, he urged that even if the confession were voluntary, it should be excluded as evidence because it was obtained after the police refused his request for counsel. ${ }^{8} \mathrm{Mr}$. Justice Clark's opinion begins by noting that the facts do not warrant holding the confession inadmissible on the ground of involuntariness. The opinion then considers the right to counsel question. ${ }^{9}$ Justice Clark does not say that there is no right to counsel before preliminary examination; the opinion concedes that the right is just as great in the pre-trial

seen his attorney motion him to silence and that there was no showing that the denial of the attorney had any coercive effect (though the defence had offered evidence on this point and the trial judge had excluded it). Motion for Rehearing by Defendant in Error, pp. 2-3, People v. Escobedo, supra. See 190 N.E.2d at 830.

4. Id. at 828,829 .

5. Escobedo denied that he understood what the attorney called to him but he admitted that he saw him motion him to silence. Id. at 830 .

6. These statutes show a legislative policy against the police or other public officers insulating a person from his attorney, but it does not follow that the legislature intended that the statute operate to insulate the person from the police or other public officials.

Id. at 831 .

7. 357 U.S. 433 (1958). The facts are detailed id. at 435-37.

8. These assertions of Crooker are very similar to the two questions presented by Escobedo. Petition for Certiorari, p. 2, Escobedo v. Illinois, 84 Sup. Ct. 203 (1963). Crooker seems to make another assertion, that the Court should exclude the evidence solely because the police had failed to bring him before a magistrate as was required by California law. The Court dismissed the problem as one of state law and administration, thus refusing to apply McNabb-Mallory to the states. Since there is no constitutional requirement that there be a magistrate's hearing, such an application would have been extremely forced. 357 U.S. at 437,439 n.4. See note 69 infra.

9. Id. at 437-38. 
stages of the criminal process as at trial. ${ }^{10}$ Rather, Justice Clark reasons that, just as due process (as then interpreted) does not demand the reversal of every state court case which denies a man appointed counsel, ${ }^{11}$ so also due process does not demand the exclusion from a state trial of every confession made after the denial of counsel. The Court will look at the totality of the circumstances in the police procedure to determine whether the standards of "fundamental fairness" have been violated by the denial of counsel. The question apparently reduces to whether the petitioner was so well able to represent himself in the process that the absence of counsel did not render him helpless to resist the state. In the case of Crooker, the Court thought his age, his experience, his knowledge of his legal rights all militated against excluding his confession on due process grounds. ${ }^{12}$

The holding in Crooker, then, turns not so much on the right as the remedy. There may be a right to counsel in the police station, but it is not so absolute as to demand in every case the exclusion of evidence in a state trial. Yet Crooker was decided before Gideon v. Wainwright, ${ }^{13}$ in which the Court repudiated the "fundamental fairness" test relied on in Crooker and held that the right to counsel at trial was so fundamental that a state conviction of a man without counsel could under no circumstances meet the requirements of due process. To the extent that Gideon thus undercuts the basis of Crooker, a reconsideration of that case is now plainly due.

The basic question which Escobedo poses is how far a right traditionally associated with hearings before judicial officers should be extended into the interrogation process. In search of a basis for answering this question, the bulk of this Comment will be devoted to an examination of the common law history of the right to counsel, seeking to determine the value and function of that right. If the right can be thus understood, it may then be possible to essay a meaningful comparison between the interest of the individual in having counsel at interrogation and the interest of the state in preserving the administration of criminal justice - the balance attempted by Justice Clark in Crooker. Such a comparison will necessarily require examination of the practice of interrogation and the arguments most frequently offered in support of its necessity to the criminal process, as well as the means by which individual interests in the presence of counsel at interrogation might be vindicated. The Comment will consider these issues entirely from constitutional perspective. Since there is a paucity of law on the topic of the right to counsel for misdemeanors, the inquiry is confined to felonies. ${ }^{14}$

10. Id. at 439 .

11. See Betts v. Brady, 316 U.S. 455 (1942) and notes $27-28$ infra and accompanying text.

12. 357 U.S. at 440.

13. 372 U.S. 335 (1963).

14. For a discussion of the counsel problem in the context of misdemeanors, see Comment, 48 Calrf. L. Rev. 501 (1960). Cf. Harlan, J., concurring in Gideon v. Wainright, 372 U.S. at 351 ; note 46 infra. The right to counsel was at one time more assured for misdemeanors than it was for felonies. See note 132 infra and accompanying text. 


\section{Gideon and Counsel at Judicial Hearing}

\section{Right to Counsel before Gideon}

Between the leading case of Powell v. Alabama ${ }^{15}$ and Gideon v. Wainworight.$^{10}$ the doctrinal struggles relating to right to counsel centered on three issues. One debate concerned the distinction between federal and state right to counsel; the second, the distinction between retained counsel and appointed counsel; the third concerned the remedy to be applied when the right to counsel was violated. ${ }^{17}$

The right to retained counsel at a criminal trial is absolute in both state and federal courts. In neither the federal nor the state systems does it seem ever to have been denied; denial would doubtless be ample reason for grant of habeas corpus. In federal courts, the right is guaranteed by the sixth amendment $; 18$ in state courts, it is guaranteed by the due process clause of the fourteenth amendment, as well as by state constitutional provisions. ${ }^{19}$ The theory of its application through the fourteenth amendment was stated by Mr. Justice Sutherland in Powell v. Alabama.

It has never been doubted by this Court, or any other so far as we know, that notice and hearing are preliminary steps essential to the passing of an enforceable judgment .... What, then, does hearing include? Historically and in practice, in our own country at least, it has always included the right to the aid of counsel when desired and provided by the party asserting the right. The right to be heard would be, in many cases, of little avail if it did not comprehend the right to be heard by counsel. ${ }^{20}$

The right to appointed counsel at criminal trials in the federal courts is guaranteed by the sixth amendment. The guarantee was first asserted in

15. 287 U.S. 45 (1932).

16. 372 U.S. 335 (1963).

17. Until 1932 there were practically no Supreme Court cases considering either the implications of the 1789 Amendment to the Constitution which says, "In all criminal prosecutions, the accused shall enjoy the right ... to have the Assistance of Counsel for his defence," U.S. ConST. amend. VI, or the possibility that the 1868 Amendment which says, "No State shall ... deprive any person of life, liberty, or property, without due process of law," U.S. CoNst. amend. XIV, might have some bearing on the right to counsel. There are historical reasons for this seeming ignoring of the problem. See notes 181-84 infra and accompanying text.

An excellent treatise on the right to counsel before Gideon is Beaney, The Rught to Counsel in AMerican Courts (1955).

18. For federal cases $c f$., Glasser v. United States, 315 U.S. 60 (1942); Walker v. Johnston, 312 U.S. 275 (1941); Johnson v. Zerbst, 304 U.S. 458 (1938).

19. For state cases of., Cash v. Culver, 358 U.S. 633 (1959); Moore v. Michigan, 355 U.S. 155 (1957); Uverges v. Pennsylvania, 335 U.S. 437 (1948); Avery v. Alabama, 308 U.S. 444 (1940).

The right to counsel is guaranteed by the constitution of every state except Virginia. See Fellman, The Right to Counsel Under State Law, 1955 WIs. L. Rev. 281. In Virginia the "law of the land" clause has been held to embrace counsel. Cottrell v. Commonwealth; 187 Va. 351, 46 S.E.2d 413 (1948). See also VA. CoDE 19.1-214 (1960).

20. 287 U.S. at $68-69$. 
Johnson v. Zerbst, ${ }^{21}$ in which the Court concluded that a right so necessary for safeguarding "fundamental human rights" could not depend for its exercise on the financial situation of the accused. The purpose of the right, the Court noted, was "to protect an accused from conviction resulting from his own ignorance of his legal and constitutional rights." 22 If an accused cannot afford counsel the Court must appoint one; if it fails to do so, habeas corpus will lie. ${ }^{23}$

Until Gideon v. Wainwright ${ }^{24}$ the right to appointed counsel in a state trial was somewhat uncertain. Powell v. Alabama ${ }^{25}$ held that the helpless defendants on trial for their lives in the Scottsboro Cases had to have counsel, and effective counsel, appointed. The decision was based on the broad ground that a right to hearing is fundamental to due process of law, and that the right to hearing is worthless if it does not include the right to hearing through counsel. The Court subsequently said that the right to appointed counsel extended to every capital case. ${ }^{2 B}$ In Betts $v$. Brady, ${ }^{27}$ however, the Court held that the fourteenth amendment does not require the appointment of counsel in every non-capital felony case. Betts was a mature man, in full possession of his faculties, who, in a simple robbery case tried before a scrupulously fair judge without a jury, failed to establish his defense of alibi. Mr. Justice Roberts, writing for the Court, examined the history of the right to counsel and found that it was not regarded as fundamental in the English common law. Justice Roberts concluded from this evidence that it was not "a fundamental right, essential to a fair trial."28 Due process, the Court said, is

... a concept less rigid and more fluid than those [concepts] envisaged in other specific and particular provisions of the Bill of Rights .... Asserted denial is to be tested by an appraisal of the totality of facts in a given case. That which may, in one setting, constitute a denial of fundamental fairness, shocking to the universal sense of justice, may, in other circumstances ... fall short of such denial.29

Thus, the Court refused rigidly to impose upon the states responsibility to protect the right by providing for appointment of counsel. Under Betts, the denial of counsel was not an occasion for automatic reversal or habeas corpus; the Court would look at all the facts of the case to see if the accused had been denied fundamental fairness. Looking to the facts in Betts, the Court was not shocked.

As far as the temporal sweep of the right to counsel is concerned, there is already respectable doctrine in both state and federal courts requiring counsel

21. 304 U.S. 458,462 (1938).

22. Id. at 465 .

23. Id. at 468 .

24. 372 U.S. 335 (1963).

25. 287 U.S. 45 (1932).

26. Avery v. Alabama, 308 U.S. 444 (1940). See Bute v. Illinois, 333 U.S. 640

(1948). Hamilton v. Alabama, 368 U.S. 52 (1961) is the first direct holding on the topic.

27. 316 U.S. 455 (1942). Facts $i d$. at 456-59, 472-73.

28. Id. at 471 .

29. Id. at 462 . 
for a considerable period of time before trial. The right to counsel at trial involves the right to effective counsel, and it is uniformly held that counsel must have sufficient time to prepare and to consult with his client before the trial. $^{30}$ In the federal courts the right to appointed counsel does not seem to attach until arraignment, when the accused is formally charged and required to plead. ${ }^{31}$ The defendant need not take the offer of counsel at arraignment, but must be informed of his right. The right to retained counsel at arraignment in the federal courts is unqualified. In the state courts, the right to retained counsel at arraignment also is unqualified. ${ }^{32}$ The right to appointed counsel at arraignment was, until Gideon, governed by the same standards of fundamental fairness which governed the appointment of counsel for trial. ${ }^{33}$ But in 1961 the Supreme Court held that it is automatically prejudicial to make a man plead in a capital case without counsel. ${ }^{34}$

The right to counsel cases have arisen primarily in the context of arraignment and post-arraignment proceedings. Prior to arraignment the issue of counsel tends to become merged with problems of arrest, false imprisonment, forced confession, police interrogation, and other peculiarly pre-trial problems. Nonetheless, there was a fairly clear body of doctrine before Gideon that there was a right to retained counsel but not to appointed counsel at preliminary hearing in the federal courts. ${ }^{35}$ Courts seemed to rest this right more on fifth amendment principles of due process and fair hearing than on the command of the sixth amendment. ${ }^{36}$ In White $v$. Maryland ${ }^{37}$ the Supreme Court held

30. See Powell v. Alabama, 287 U.S. 45, 59 (1932); Avery v. Alabama, 308 U.S. 444, 446 (1940); cases collected in 23 A.L.R. 1382 (1923), 54 A.L.R. 1225 (1928) and 3 A.L.R. 2d 1003 (1949).

31. FED. R. CRIMr. P. 44, has never been held to apply before arraignment.

After Johnson v. Zerbst there was some doubt as to the scope of the holding; in' cases in which the defendant had pleaded guilty without asking for counsel there was a tendency to imply from his silence a waiver of counsel. Since the case of Walker v. Johnston, 312 U.S. 275 (1941), however, the rule has been that waiver of counsel at pleading must be "explicit" and "intelligent." See BEANEY, op. cit. supra note 17, at 66-72.

32. Chandler v. Fretag, 348 U.S. 3 (1954).

33. Compare Bute v. Illinois, 333 U.S. 640 (1948), with Moore v. Michigan, 355 U.S. 155 (1957).

34. Hamilton v. Alabama, 368 U.S. 52 (1961).

35. See Wood v. United States, 128 F.2d 265 (D.C. Cir. 1942); United States v. Bollman, 24 Fed. Cas. 1189 (No. 14622) (C.C.D.C. 1807). Cf. Ex parte Chin Loy You, 223 Fed. 833 (D. Mass. 1915). See also FEd. R. CRIMr. P. 5(b).

36. Perhaps the courts chose the due process doctrine because Johnson v. Zerbst, 304 U.S. 458 (1938), seemed to hold that wherever the sixth amendment applied there must be appointed as well as retained counsel, and the courts seemed hesitant to impose the expense resulting from the requirement of appointed counsel at this stage of the proceedings. Perhaps the courts chose due process simply because the first modern case on the topic, Ex parte Chin Loy You, supra note 35, was a deportation case in which the specifically criminal procedures demanded by the sixth amendment did not apply. The earliest case in the area, however, United States v. Bollman, supra note 35, seems to have gone down on sixth amendment grounds.

37. 373 U.S. 59 (1963). White was decided after Gideon but did not rely on it. 
that where the accused in a capital case was required to plead at preliminary hearing without counsel, his plea could not be introduced in evidence against him at trial. No other state decision on the right to counsel at preliminary hearing has ever reached the Court $;^{38}$ the state cases hold generally that there is a right to retained counsel but no right to appointed counsel. ${ }^{30}$ Some of these decisions rest on due process notions of fair hearing; others on state statutes which specifically require that retained counsel be admitted at preliminary hearing or which generally forbid state officials to deny a man access to counsel at any time. ${ }^{40}$ The remedy for the denial of the right at preliminary hearing is uncertain. Denial of other rights at preliminary hearing has resulated in vacating of the whole proceeding, requiring the state to begin again ; 41 other precedent suggests that anything obtained at the hearing which is damaging to the uncounseled defendent must be excluded at trial.42

\section{Right to Counsel after Gideon}

It was against this background that Gideon $v$. Wainwright ${ }^{43}$ was decided. Gideon was convicted in a Florida court under circumstances which the Court conceded to be indistinguishable from those of Betts. Both men were on trial for property crimes; both were mature men who conducted reasonably competent defenses. Justice Black, for the Court, noted that in the years since Betts it had become increasingly obvious that Betts was an anomaly in the field of right to counsel. ${ }^{44}$ Under Betts, the determination under the fourteenth amendment of right to counsel at trial depended on a finding of fundamental fairness, while most of the early cases proceeded in a manner which suggested that the right to counsel under the fourteenth amendment was equivalent to that under the sixth, and thus absolute. Justice Black contrasts the position of the uncounseled, indigent defendant with that of the state, which has unlimited resources for investigation and counsel at its command. If the wealthy

38. But of. In re Groban, 352 U.S. 330 (1957) holding that there is no right to counsel before a fire warden's hearing from which criminal prosecution might result. See also $i d$. at 337 (Black, J. with Warren, C.J., Douglas and Brennan, J.J. dissenting).

39. See Martin v. Edmondson, 176 Kan. 374, 270 P.2d 791 (1954); Lambus v. Kaiser, 352 Mo. 122, 176 S.W.2d 494 (1943) ; Lyons v. State, 77 Okla. Cr. 197, 242-44, 248, 138 P.2d 142, 166-68 (1943); State v. Braasch, 229 P.2d 289 (Utah 1951), cert. devtied, 342 U.S. 910 (1952); Roberts v. State, 145 Neb. 658, 17 N.W.2d 666 (1945); Note, 44 KY. L.J. 103 (1955).

40. Due process: Martin v. Edmondson, supra note 39; Lambus v. Kaiser, supra note 39. Lyons v. State, supra note 39. Statute: In re Both, 200 App. Div. 423, 192 N.Y. Supp. 822 (1922). Among the statutes, see N.C. Gen. Stat. ANN. \$\$ 15-87, 15-88 (1953); Texas Code Crim. Proc. art. 245 (1954).

41. See People v. Salas, 80 Cal. App. 318, 250 Pac. 526 (1926). Cf. In re Flodstrom, 134 Cal. App. 2d 871, 277 P.2d 101 (1954); State v. Smith, 35 So. 42 (Ala. 1903).

42. See White v. Maryland, 373 U.S. 59 (1963) ; Wood v. United States, 128 F.2d 265 (D.C. Cir. 1942).

43. 372 U.S. 335 (1963).

44. Id. at 341 . 
defendant may hire a lawyer to help him against this amassed power of the state, why should the poor defendant be denied the opportunity of legal aid?

From the very beginning, our state and national constitutions and laws have laid great emphasis on ... safeguards designed to assure .... [that] every defendant stands equal before the law. This noble ideal cannot be realized if the poor man charged with crime has to face his accusers without a lawyer to assist him. ${ }^{45}$

In the light of these considerations, the Court held the right to counsel to be one of "those guarantees of the Bill of Rights which are fundamental safeguards of liberty immune from federal abridgment [and] . . . equally protected against state invasion by the Due Process Clause of the Fourteenth Amendment." 40

The implication of Gideon for the right to counsel as outlined above are fairly clear. The Court will no longer refer to fundamental fairness as the standard by which it determines whether a man should have counsel at trial in the state courts; it will apply an absolute standard. The same conclusion undoubtedly applies at arraignment. Only the defendant who explicitly and intelligently waives counsel will now appear at trial or arraignment unaided. The reasoning of Gideon also seems to require that there be a right to appointed counsel whenever there is a right to retained counsel. The present distinction between right to retained counsel and right to appointed counsel at preliminary examination in federal and state courts may thus be expected to fall. ${ }^{47}$

The principal objection to an extension to preliminary hearing of the right to appointed counsel is practical - that the cost of administering such a program would be prohibitive. This was the objection raised when the Court set about deciding Betts v. Brady; it is an argument to which the Court seems

45. Id. at 344 .

46. Id. at 341 .

Six justices joined in Justice Black's opinion; there were three concurrences. Mr. Justice Douglas agreed with the Court's holding that the sixth amendment right to counsel applied through the fourteenth but wished the Court had gone further to declare that all the procedural rights of the Bill of Rights applied to the states through the fourteenth. Id. at 345-47. Mr. Justice Clark agreed with the Court that Betts was an anomaly in that it made a distinction betweem capital and non-capital cases. This distinction, he declared, was meaningless for the right to counsel. Id. at 347-49. Mr. Justice Harlan concurred with the result but wished to dissociate himself from any notions of incorporation of the Bill of Rights in the fourteenth amendment which might have been inherent in the Court's opinion. Id. at 349-52. See generally Israel, Gideon v. Wainright: The "Art" of Overruling, 1963 The Suprense Court Review (Kurland ed.) 211 (1963).

47. White v. Maryland, 373 U.S. 59 (1963), may be viewed as a step in this direction though the opinion does not mention Gideon, but rather goes down on the strength of Hamilton v. Alabama, 368 U.S. 52 (1961), the case which required that counsel be appointed for those pleading in a capital case. A line of cases seems to be developing which demand appointed counsel at preliminary hearing if, and only if, something "critical" takes place then. See Pettit v. Rhay, 383 P.2d 889 (Wash. 1963); State v. Kirkland, 197 A.2d 876 (App. Div. N.J. 1964). 
now to pay little attention. ${ }^{48}$ If preliminary examination continued to play the small part in the criminal process that it now plays, the cost would not be too great. ${ }^{49}$ On the other hand, a right to appointed counsel during this hearing might make the hearings considerably more common. Counseled defendants might not waive hearing so often, and might try to prevent the indefinite postponements of the hearing which often enable prosecutors to avoid it altogether by resort to indictment. ${ }^{50}$ This result would not add expense to the trial process in every case. Some cases might be dismissed earlier, saving expense for both the state and the defendant; in others the issues might be clarified, shortening the trial process. There would indubitably, however, be a residuum of extra expense. What this expense might be can only be approximated. In California, which has had appointed counsel at preliminary hearings for a number of years, the expense has not proved inordinate, ${ }^{51}$ and criminal statistics suggest that preliminary hearing has become a more significant part of the process, with advantages resulting for both the state and the accused.52

\section{Gideon and the Police Process}

After a man is arrested and before he appears before a magistrate, there is a separate proceeding held in the police station. In this proceeding the police will book, photograph, and fingerprint the man, perhaps display him in a line-up, and almost invariably interrogate him, over a period which may last from a few minutes to several days. ${ }^{53}$ Not only are various investigative procedures carried out at this time, but there is a decision to be made, whether the police will press the charges against the man and bring him before the magistrate or whether they will release him. ${ }^{54}$ The accused must make a de-

48. Cf. Draper v. Washington, 372 U.S. 487 (1963); Griffin v. Illinois, 351 U.S. 12 (1956).

49. See generally A. Goldstein, The State and the Accused: Balance of Advantage in Criminal Procedure, 69 YaLE L.J. 1149, 1166-69 (1960). Comment, Metropolitan Criminal Courts of First Instance, 70 Harv. L. Rev. 320, 323-29 (1956). In the District of Columbia, under a haphazard system of appointment, lawyers almost invariably advise waiver of preliminary hearing. See Letter from Myron P. Ehrlich to David G. Bress, January 15, 1958, in Goldstein \& Goldstein, Cases and Materials on Criminal Procedure, ch. vi, 31-33, 1961 (unpublished materials in Yale Law Library).

50. See United States v. Gray, 87 F. Supp. 436 (D.D.C. 1949).

51. See People v. Williams, 124 Cal. App. 2d 32, 268 P.2d 156 (1954); Cal. Penal CoDe $\$ 866.5$ (1957); id. § 859 (Supp. 1963); Cuff, Public Defender System: The Los Angeles Story, 45 Minn. L. Rev. 715, 730 (1961); David, Institutional or Private Counsel: A Judge's Vieze of the Public Defender System, id. 753, 768.

52. The criminal statistics of the state do not show what counsel has done for the preliminary hearing, but the unusually large dismissal of felony complaints for insuffcient evidence suggests that counsel's activity is making this hearing a significant screen. See State of Calif., Dept. of Justice, Crime in Calif. 1959, 46; id. 1960, 78; id. 1961, 89.

53. For typical police procedure, see Kenney \& Willianis, Police Operations; Polictes aNd Procedures (1960).

54. See J. Goldstein, Police Discretion Not to Invoke the Criminal Process: Low Visibility Decisions in the Administration of Justice, 69 Y AIE L.J. 543 (1960). 
cision as well; whether he will confess his guilt and go on to plead guilty or whether he will attempt to defend himself against the charges. If the committing magistrate turns the man over to the jail authorities - that is, in the typical state, moves him from the police detention cell to the county jail the police may come to the county jail and interrogate him there. If he posts bond, they may come to his home. Neither practice, however, seems common, and, as a general rule, police interrogation is over once the accused moves out of the hands of the police. ${ }^{55}$

Since the entire police process is substantially hidden from public view, little is known about any aspect of these decisions. Though the literature on police interrogation is vast, ${ }^{56}$ the present state of our knowledge about this area is inadequate. ${ }^{57}$ Such important questions as the percentage of crimes solved by confessions obtained through interrogation are still unanswered. It might be possible to ascertain the percentage of trials in which confessions play a part, but this alone would give us a very distorted picture since ninety per cent of the people convicted of crime are convicted on a plea of guilty. ${ }^{58}$ Nor has any thorough study been made since the Wickersham Report on just what methods are employed by the police during interrogation.59 We know just enough about the process to define the relevant area of inquiry.

Formal interrogation by the police while a man is in custody falls into two sometimes overlapping categories. ${ }^{60}$ Often a man has been "picked up" not because the police suspect him of guilt but because he is thought to know something of the crime under investigation; in this case the police are after not a confession but simply evidence of the crime. The legal problems involved

55. See note 268 infra.

56. See Way, The Supreme Contrt and State Cocrced Confessions, 12 J. PuB. L. 53 (1963) ; Ritz, Twenty-Five Years of State Criminal Confessions in the U.S. Supreme Coutt, 19 WASH. \& LEE L. Rev. 35, 202 (1962); Symposium: Police Interrogation Privileges and Lintitations, 52 J. CRIMr. L., C. \& P.S. 1-73 (1961), in Police Power and Indrvidual Freenom 129-212 (Sowle ed. 1962) [hereinafter cited as Sowle]. Bibliography in Hearings before the Subcommittee on Constitutional Rights of the Senate Committee on the Judiciary, 85th Cong., 2d Sess., ser. 13, at 748-65 (1958) [hereinafter referred to as 1958 Scnate Hearings], reprinted in 50 J. CRIM. L., C. \& P.S. 175-85 (1959). Among the manuals of interrogation are: Inbau \& ReID, Criminal Interrogation and Confessions (1962); O’Hara, Fundamentals of Criminal Investigation (1956) ; Krdd, Police Interrogation (1940).

57. See Weisberg, Police Interrogation of Arrested Persons, 52 J. CRIM. L., C. \& P.S. 21 (1961), in SowLe at 153.

58. See A. Goldstein, supra note 49, at 1163 n.37; Orfield, Criminal Procedure from ARrest to Appear. 297-98 (1947).

59. U.S. National Commission on Law Observance and Enforcenent, Report on LAwLessNess IN ENForCenient of THE LAW (1931) [hereinafter cited as 4 Wickershamr. See Equal Justice under the Law, in Justice, 5 U.S. Commisston on CTutL Rights Reports 5-28 (1961). The American Bar Foundation's promised study of the administration of criminal justice in the United States should follow up Wickersham, but so far none of this has appeared. Sherry, The Administration of Criminal Justice in the United States; Plan for a Survey (1955).

60. See INBaU \& Rem, op. cit. supra note 56, at 21, 88, 116. 
in this interrogation of witnesses chiefly concern the law of arrest. If the police have no probable cause to believe a person guilty of a particular crime, they have no right to arrest him; yet such "arrest" practices apparently are prevalent. ${ }^{61}$ To allow counsel for these persons would certainly cut down on the number of illegal arrests. Because reliable information is unavailable, it is difficult to predict what effect such an extension would have on the efficiency of the investigative process. ${ }^{62}$

Fears of the implications of change are greatest when the interrogation of suspects, rather than witnesses is at issue. In such cases the police are reasonably certain of a man's guilt; they seek not only evidence but also a confession, or, failing that, incriminating admissions. Although they seem tractable on the subject of counsel for witnesses, police insist that interrogation of suspects cannot be conducted in the presence of counsel. ${ }^{63}$ What is learned from interrogating a suspect is more likely to be repudiated than what is learned from interrogating a witness; the suspect, unlike the witness, may do his own cause great harm by his answers to questions. The methods used to obtain admissions from a suspect are more likely to be questionable than the methods used on a witness, for the police, who need the witness' testimony at trial, have reason to treat the latter in a kindly fashion. Anything obtained from a suspect, however, will be admissible at trial, whether the accused testifies or not, by the admissions exception to the hearsay rule. ${ }^{64}$

In the federal criminal system the $M c N a b b-M a l l o r y$ rule ${ }^{65}$ has indirectly extended the domain of the right to counsel by severely limiting the duration of the low-visibility process at the police station. Rule Five (a) of the Federal Rules of Criminal Procedure requires the police to bring an arrested person before a magistrate "without unnecessary delay." Once a man is before the magistrate he is told of his procedural rights, including the right to counsel, and is given an opportunity to obtain counsel. The $M c N a b b$-Mallory rule, adopted by the Supreme Court as a means of enforcing Rule Five, requires

61. See Foote, Safeguards in the Law of Arrest, 52 Nw. U.L. REv. 16 (1957). See generally BARTH, The Price of LIBERTy (1961).

62. That the prosecutor has other methods for interrogating unwilling witnesses, before a Grand Jury or at a preliminary hearing, should make a witness willing to answer questions in a more informal setting.

63. Justice Jackson so argues in Watts v. Indiana, 338 U.S. 49, 59 (1949) (concurring opinion). The argument is assumed in Crooker v. California, 357 U.S. 433, 441 (1958).

64. 3 WigMrore, EvIDENCE $\S 815-16$ (3d ed. 1940). See generally id. at $\S \S 817-67$ and $i d$. at 82-134 (1962 Supp.).

65. Mallory v. United States, 354 U.S. 449 (1957) ; McNabb v. United States, 318 U.S. 332 (1942).

The literature on McNabb-Mallory is vast: See Bibliography in 1958 Senate Hearings at 762-65. More recent materials are Police Detention and Arrest Privileges: An International Symposium, 51 J. CRLAr. L., C. \& P.S. 385 (1960), in SowLE at 9-73; Note, Pre-Arraignment Interrogation and the McNabb-Mallory Miasma, 68 YALE L.J. 1003 (1959) ; Hogan \& Snee, The McNabb-Mallory Rule: Its Rise, Rationale and Rescut, 47 GEO. L.J. 1 (1958). 
the exclusion at trial of confessions and admissions ${ }^{66}$ obtained during police custody extending for an unnecessary length of time. Though the rule does not specifically relate to counsel, it helps to effectuate, and was intended to effectuate the right, ${ }^{67}$ by ensuring that the magistrate's advice about counsel is given at any early stage in the process. And although counsel's right to be present at interrogation is not established in the federal criminal procedure, it appears that once this hearing is held, and counsel obtained, interrogation, for all practical purposes, stops. ${ }^{68}$ Since the $M c N a b b$-Mallory rule is not a constitutional doctrine, but rather is grounded in the Court's powers of supervision over the administration of federal justice, it does not apply to the states. ${ }^{69}$

When it wishes to control state police processes the Supreme Court relies on constitutional doctrines, oriented to specific police abuses, such as the doctrine of coerced confession or the doctrine of right to counsel. Crooker is one of the two cases in which the Court has considered overthrowing a confession solely because it was obtained after a denial of counsel. The other case, Cicenia v. LaGay, ${ }^{70}$ was a companion case to Crooker, and was treated by the Court in far more cursory fashion. The petitioner in Cicenia had been

66. It is unclear whether only confessions and admissions are excluded by the rule or whether all evidence, including such things as gunpowder tests and fingerprints, obtained beyond the time of "necessary delay" is excludable. In Watson v. United States, 249 F.2d 106 (D.C. Cir. 1957) the issue was raised obliquely but the case went down on the exclusion of a confession. In United States v. Klapholz, 230 F.2d 494 (2d Cir.), cert. denied, 351 U.S. 924 (1956), there is dictum to the effect that "all" evidence is to be excluded. See generally Upshaw v. United States, 335 U.S. 410 (1948); United States v. Carignan, 342 U.S. 36 (1951).

67. Mallory v. United States, 354 U.S. 449, 455 (1957). See also Memorandum on the Detention of Arrested Persons and Their Production before a Committee Magistrate, in 2 Chaffee, Docuarents in Fundastental Huaran Rights 541 (1951-52).

68. See note 268 infra and accompanying text.

69. 318 U.S. 332, 341 (1942). It has been argued that Wong Sun v. United States, 371 U.S. 471 (1963), has made McNabb-Mallory a constitutional doctrine by holding that a confession which was the product of an illegal arrest and entry must be excluded under the Mapp doctrine. See Broeder, Wong Sun v. United States: A Study in Faith and Hope, 42 NEB. L. REv. 483, 557-65 (1963). Wong Sun, however, was a federal case, and the statements obtained were clearly the product of the arrest and seizure by the officers. 371 U.S. at 484-87. The Court distinguished the case in which the evidence would not have come to light "but for" the illegal arrest from the case at bar in which the illegal evidence was the product of an "exploitation" of illegality. Id. at 488. In any case the Court will have difficulty making arraignment "without unnecessary delay" into a constitutional doctrine since there is no constitutional requirement that there be a magistrate's hearing. Escobedo is raising arguments based on Wong Sinn before the Court though he will have to overcome an initial difficulty of showing the illegality of his arrest. See Brief for the Petitioner, pp. 25-27, Escobedo v. Illinois, 84 Sup. Ct. 203 (1963); Petition for Certiorari, $i d$. at 7.

One state, Michigan, has adopted the $M c N a b b$ rule by judicial decree. People v. Hamilton, 359 Mich. 410, 102 N.W.2d 738 (1960). Another state, Connecticut, has adopted a modified version in statute. Cons. Public Acrs 1963, No. 126.

70. 357 U.S. 504 (1958). Facts id. at 505-06; Application of Cicenia, 148 F. Supp. 98, 99 (D.N.J. 1956). 
surrendered by his attorney to the police, who proceeded to question him for seven hours, until he confessed. Meanwhile, his attorney was at the door, demanding that he be allowed to see his client. The Court held the confession properly admitted at trial. Although the Court found the procedure followed by the police in Cicenia distasteful, it discovered no compelling necessity to warrant what it considered the extraordinary measure of upsetting a state conviction and excluding evidence which the state court had found admissible. There was no careful examination of the petitioner's age and experience to see whether the police procedure shocked the judicial conscience as there had been in Crooker. It has been suggested, however, that Cicenia's consultation with his lawyer before going to the police station affected the Court's decision by raising a presumption that he knew of his rights. ${ }^{71}$ The Court's citation of Crooker for the proposition that there is no right to counsel before preliminary examination ${ }^{72}$ is surprising, since Crooker contains no such statement and in fact suggests the contrary to be true; the brevity of the opinion and the fact that it followed so closely on Crooker justify the conclusion that the citation expresses little more than a desire to avoid further elucidation of the reasoning developed in the earlier case. Subsequent cases in the lower federal courts, dealing with both state and federal claims, seem to have preferred Crooker itself to Cicenia's reading of it, and have treated the denial of counsel as an issue independent of the voluntariness of the challenged confession. At least three courts have found that in some cases fundamental fairness demands that the court exclude a confession because counsel was denied, even in the absence of any finding that the confession was involuntary. ${ }^{73}$

The right to counsel and the implications of Gideon are less clear in the stages prior to judicial hearing. If there were a federal right to counsel in the police station under the sixth amendment, this right would presumably apply to the states under Gideon, since that case seems to render the fourteenth amendment right to counsel co-extensive with the sixth amendment right. The Supreme Court, however, has dealt with the problem of the federal right to counsel in the police station only indirectly, through the medium of its power to make evidentiary rules for the federal courts, so that it has never had to reach the issue of a sixth amendment right. Even so, Gideon may effect the validity of the Crooker doctrine. The Court's indication in Crooker that it would determine the right to counsel in the police station on a case by case basis, examining the totality of the circumstances, was premised upon the

71. Seje Lee v. United States, 322 F.2d 770, 773 (5th Cir. 1963).

72. 357 U.S. at 508 .

73. See Lee v. United States, 322 F.2d 770 (5th Cir. 1963); Griffith v. Rhy, 282 F.2d 711 (9th Cir. 1960), cert. denied, 359 U.S. 1015 (1961); and previous to Crooker, see Ex parte Sullivan, 107 F. Supp. 514 (D. Utah 1952) rehearing sub nom. Sullivan v. Utah, 126 F. Supp. 64 (1954), reversed, 227 F.2d 511 (10th Cir. 1955), cert. devied sub nom. Braasch v. Utah, 350 U.S. 973 (1956). See also Weisberg, stpra note 57, at 42-43, in Sowre 153, 178. 
similar approach of Betts $v$. Brady ${ }^{74}$ to the problem of the right to appointed counsel at trial. Now that this method of determination has been overruled so far as trial is concerned, it would not be illogical for the Court to declare that the method was also invalid as a means for determining the right to counsel before trial.

The same arguments which were urged against fundamental fairness as a standard for determining the right to counsel at trial may be urged against it as a standard for determining the right to counsel in the police station. ${ }^{75} \mathrm{~A}$ case decided by the standard of fundamental fairness has limited value as precedent since it provides only vague principles to guide those who must enforce the standard. If it is almost impossible for a lawyer to predict how the Court will go on a given set of facts, a policeman, with only limited training in the law, must be even more in the dark as to the standard that the Court is laying down. ${ }^{76}$ Further, the "fundamental fairness" approach as applied to counsel problems involves a retrospective determination of prejudice; it involves the court in speculation of what might have been. In some cases one may look back and say that had counsel been present, the case would have gone the other way; in others, it is simply impossible to tell. A closer examination of the seemingly simple facts of Betts, for example, reveals that under proper cross-examination the state's principal witness might not have seemed so trustworthy nor Betts' alibi so implausible. ${ }^{77}$ One of the most remarkable documents to come out of the Crooker case shows that Crooker, far from being the knowledgeable law student pictured in the Court's opinion, was a very confused young man, on the verge of a complete nervous breakdown, who confessed to committing a crime in a way in which he could not possibly have committed it. ${ }^{78}$ The Court cannot tell what facts an early investigation by competent counsel would have revealed, not only facts bearing on the question of whether the accused committed the act charged but also facts bearing on the issue of mens rea, on the degree of criminality, or on the possible issue of insanity. Finally, the standard of fundamental fairness creates a curious hierarchy of constitutional rights. By applying the standard of fundamental fairness, the Court is in effect saying that there are some rights which any man accused of crime may have and there are some which he may have only if he is ignorant, unfortunate, colored, young, or inexperienced.

74. 316 U.S. 455 (1942).

75. Rothblatt \& Rothblatt, Police Interrogation: The Right to Counsel and Prompt Arraigument, 27 BROOKLYN L. Rev. 24, 31-33 (1960).

76. The police themselves frequently argue for definite standards from the courts. See Coakley, Restrictions in the Law of Arrest, 52 Nw. U.L. Rev. 2 (1957) ; Inbau, Restrictions in the Law of Interrogation and Confessions, id. at 77; 1958 Senate Hearings at 88 (statement of Joseph D. Lohman) ; Lumbard, The Adninistration of Criminal Justice: Some Problems and Their Resolution, 49 A.B.A.J. 840 (1963).

77. See Kamisar, Right to Counsel and the Fourteenth Amendment: A Dialogue on the Most Pervasive Right of an Accused, 30 U. Crr. L. Rev. 1, 42-56 (1962).

78. See Crooker's statement in Pretryman, Death and the Supreme Court, 175208 (1961). 
That such a hierarchy of rights should be associated with due process of law is especially ironic in the face of our notions of equal protection of the laws and the equality of all persons before the law.

Not only does Gideon refuse to apply the standard of fundamental fairness to right to counsel questions, but it also calls for a return to the absolute standard of counsel expounded in Powell. Justice Sutherland's dictum in Powell that the accused has a right to counsel at "every step in the proceedings against him,"78 might well be thought to imply that the right is just as valid in police proceedings as it is in judicial. Chief Justice Warren, and Justices Black, Douglas, and Brennan dissented in Crooker on the ground that the right to counsel applies absolutely to every stage of the criminal proceeding, including the police stage $;^{80}$ each of these Justices has reaffirmed his views in subsequent cases. ${ }^{81}$ Other members of the Court have shown some hesitancy to apply constitutional doctrines to the police stage of state criminal proceedings. Yet it is possible to speculate that this hesitancy arises more from a concern for the remedy to be applied when state officials violate an accused's constitutional rights than from the propriety of declaring the right itself. Such certainly proved the case in the search and seizure field, where the Court discovered the constitutional right ${ }^{82}$ some fourteen years before it found an exclusionary rule necessary to enforce it. ${ }^{83}$ In fact, Justice Clark's opinion in Crooker seemed to recognize the right, but declared that, under the circumstances, no remedy would be afforded. Given the subsequent adoption, in Mapp $v$. Ohio, ${ }^{84}$ of a rule requiring exclusion of evidence in state court proceedings if that evidence was discovered by reason of an unreasonable search and seizure, recognition and enforcement of a right to counsel during the police stage of criminal proceedings seem quite possible.

\section{The Analysis of Crooker}

If the Court is going to abandon the "fundamental fairness" approach of Crooker, the standard of Gideon is the most obvious alternative. There are, however, differences between Gideon and Crooker which might lead the Court to be wary of declaring that there is an absolute right to counsel in the police stage. The striking thing about Gideon is that the only opposition to it, with

79. 287 U.S. at 69.

80. 357 U.S. at $441-48$.

81. See, e.g., Culombe v. Connecticut, 367 U.S. 568, 637-41 (1961) (Douglas and Black, JJ., concurring); Spano v. New York, 360 U.S. 315, 324-26 (1959) (Douglas, Black and Brennan, JJ., concurring); id. at 326-27 (Stewart, Douglas, and Brennan, JJ., concurring) ; Ashdown v. Utah, 357 U.S. 426, 431-32 (1958) (Douglas and Black, JJ., dissenting) ; Cicenia v. LaGay, 357 U.S. 504, 511-12 (1958) (Warren, CJ., Douglas and Black, JJ., dissenting). Cf. Ohio ex rel. Eator v. Price, 364 U.S. 263, 274-76 (1960)

(Warren, CJ., Douglas, Black, and Brennan, JJ., espousing "selective incorporation");

Henkin, "Selective Incorporation" in the Fourteenth Amendment, 73 YALE L.J. 74 (1963).

82. Wolf v. Colorado, 338 U.S. 25 (1949).

83. Mapp v. Ohio, 367 U.S. 643 (1961).

84. Ibid. 
its overruling of Betts, came from those who argued that the Supreme Court should not force a change of policy upon the states. ${ }^{85}$ At the time of Betts, a decision to require appointment in felony cases would have forced thirteen states to make some change in policy; by the time of Gideon only four states were substantially affected. ${ }^{86}$ On the other hand, no state commands the presence of counsel in the police station and only two states, Connecticut and Michigan, have limited the scope of the police process with rules similar to $M c N a b b$-Mallory. ${ }^{\mathrm{st}}$ Thus, while the Court's decision requiring appointed counsel at trial followed the lead of most of the states, a decision requiring even retained counsel in the police station would force a change upon almost all states. When it comes to consider the overruling of Crooker, the Court will be strongly urged to balance against the interest of the accused in having counsel at interrogation the states' interest in avoiding fundamental and perhaps expensive changes in the administration of criminal justice.

In examining these opposing interests in Crooker ${ }^{88}$ Justice Clark weighed the interest of the accused in a right which he found was historically not fun-

85. See Brief for the Respondent, pp. 47-56, Gideon v. Wainwright, 372 U.S. 335 (1963). See also Brief for Alabama as Amicus Curiae, pp. 2-13, ibid.

86. Twenty-two states submitted amicus briefs urging that Betts was "an anachronism when handed down"; only two states submitted briefs to the contrary. 372 U.S. at 345. Only four states, Florida, Alabama, North and South Carolina did not require either by statute or practice appointment of counsel in felony cases involving a substantial sentence (3-5 years and up). Kamisar, Right to Counsel and the Fourteenth Amendment, 30 U. Cri. L. Rev. 1, 14-20 (1962). See Jaffee, Legal Escape, This Week, Feb. 16, 1964, at 4-5, for an interesting example of popular reaction to a Supreme Court decision.

Betts was also unpopular in legal literature. See, e.g., Kamisar, supra; Right to Counsel: A Symposium, 45 MINN. L. REv. 693 (1961); BEANEy, op. cit. supra note 17, at 299-335.

87. A number of states have statutes designed to provide the accused with counsel at an early stage in the process. See Car. Penal Code \& 825 (1959); Irr. Rev. Stat. ch. 38 $\S 477$ (1957); La. Rev. Stat. § 15.77 (1951); Mo. Stat. ANN. § 544.170 (1953). It may be doubted, however, whether these statutes have any impact on police policy since, like the statutes in almost every state which command prompt arraignment, they have no teeth in them and the courts have refused to build teeth into them. See note 277 infra.

In People v. Donovan, 13 N.Y.2d 148, 193 N.E.2d 628, 243 N.Y.S.2d 841 (1963), the New York Court of Appeals held 5-4 that a confession obtained during an illegal detention and after counsel had been denied access to the prisoner must be excluded at trial because the police had violated the defendant's right to counsel and his privilege against self-incrimination under the New York Constitution. See note 273 infra. Cf. People v. Noble, 9 N.Y.2d 571, 175 N.E.2d 451, 216 N.Y.S.2d 79 (1961) (confession excluded when D.A. during interrogation refused to answer defendant's query as to whether he had a right to counsel).

For Connecticut and Michigan see note 69 supra; Connecticut v. Kroezel, File no. mv-12-7131 AP, App. Div. Cir. Ct., March 5, 1963 (dismissing drunken driving charge when police after interrogation refused to allow defendant to call lawyer).

Most states do not command the presence of counsel before preliminary examination. See Pulaski v. State, 126 N.W.2d 625, 630-31 (Wis. 1964) ; People v. Kelly, 404 Ill. 281, 89 N.E.2d 27 (1949) ; Linkins v. State, 207 Md. 212, 218-19, 96 A.2d 246, 249-50 (1953); State v. Tune, 13 N.J. 203, 98 A.2d 881 (1953).

88. 357 U.S. at 439-41. 
damental against the value of interrogation, which he assumed to be the most vital part of the states' investigative process. If one strikes the balance in this way, there can be little doubt of the conclusion. The defendant's right will certainly not be absolute; the likelihood that any right of his will be enforced is slim. The question is, whether the elements brought into the inquiry by Justice Clark were accurately described, or even the only elements to be considered.

For the proposition that the right to counsel is not one of basic values of our criminal system Justice Clark relies on Justice Roberts' opinion in Betts v. Brady. ${ }^{89}$ Justice Roberts tried to measure the value of the right to counsel by looking to its history to determine how long the right had been in existence, and how much it seemed to be an integral part of the criminal process. When Justice Roberts looked at the history of counsel, he relied on those historians ${ }^{90}$ who told him that the right was essentially American in origin and that, unlike the right to trial by jury it was not a basic right in our common law heritage. He regarded the right as a recent grant of largess, given only when society could afford it, and thus to be protected only if there would be few if any undesirable effects on the state. ${ }^{21}$ Such an historical analysis leads naturally to a presumption against the right to counsel.

Justice Clark also assumes with Justice Roberts that historically the function of counsel was to help the accused work his way through the intricacies of trial and therefore, that an accused's need for counsel became greater as the trial process became more complex. Under such reasoning, there is little reason to expand the right to counsel into the police station, where legal questions are relatively simple and where there is no opportunity to make a formal defense. All the accused needs in the police station is someone to advise him of his legal rights, such as his right to silence. Crooker, said the Court, did not need counsel; he already knew his rights. ${ }^{92}$ For those who do not know their rights, others, such as the police, can advise them.

Justice Clark does not deny that the accused has other needs in the police station which might be met by the presence of counsel. He was aware of the assertions that "a person accused of crime needs a lawyer right after his arrest probably more than at any other time," 93 not only to inform him of his rights, but also to protect him from police brutality, and to begin the preparation of his defense while the case is still fresh. ${ }^{94}$ But the Justice implied

89. 316 U.S. at $465-71$.

Justice Clark also relies on 1 Cooley, Constitutionar Limitations 696-700 (Carrington ed. 1927) which gives the history substantially as Justice Roberts did.

90. For the prevailing view of the history see BEANEy, The RigHt to Counsel in American Courts 8-24 (1955); but cf. Plucknett, A Concise History of the Common Law 410 (1948); 4 Blackstone, Commentaries $* 355-56$ (Cooley ed. 1899).

91. 316 U.S. at $465-71$.

92. 357 U.S. at 440.

93. Chaffee, op. cit. supra note 67.

94. 357 U.S. at $443-48$ (dissent). 
that counsel should not serve this function, that other means of control such as the exclusion of involuntary confessions and prompt arraignment could do the job equally well. His arguments reflect a more general theory which finds two stages in the criminal process, an informal fact-finding stage, and a formal accusatorial stage. Historically, it is urged, the provisions of the Bill of Rights relating to criminal procedures were meant to apply only to the latter, which involve judicial rather than executive functions. If the provisions are applied to the police stage, the principle of the separation of powers will be violated. ${ }^{95}$

In order to judge the validity of Justice Clark's proposition as to the value and function of counsel, it is necessary to look to the history of the right. Concerning the value of counsel we shall look to see whether the right to counsel is an ancient right or a recent grant which society could afford only as it became stronger and whether when the right to counsel has been limited or denied in the past, the accused has managed to do without it. Concerning the function of counsel we shall look to see whether counsel was present in the past simply to aid with technicalities or whether he has served a broader function. Finally, if we have had counsel in the past for a particular stage in the process to serve a specific function, we shall inquire at what stage in the process today counsel should be present in order to serve that function.

Before continuing further, it is relevant to ask why Justice Clark chose to inquire into history, or, phrased more broadly, whether an inquiry into history is really useful for this kind of discussion. Police interrogation, after all, is a modern problem. Since there is no historical equivalent of police interrogation, at least in the ordinary criminal process, history is a poor source of binding precedent for the problem at hand. There is a tendency today to minimize the benefits of precedent when dealing with a problem not known in the past. This arises, perhaps, as an overreaction to recent judicial history. Many judges of the nineteenth century felt that old legal doctrine could be applied to new situations by a process of absolute deductive logic, without the need to make any value judgment. The recognition that their assumptions were false - that in applying old legal doctrine to new situations the decision can go either way depending on the values of the judge - has made judges wary of using history at all. Faced with a contemporary problem, the judge who is not satisfied to derive these values from personal prejudice will most often turn to empirical study to discover the values which are at issue. This method works well when one is dealing with a problem like child labor, which may be analyzed through statistics and which, when analyzed, reveals the choice of values clearly.

Empirical analysis is of little help, however, when the modern problem is one like police interrogation - an invisible process, about which the few known facts are contradictory, in which the effect of the probative decision cannot be measured, and concerning which sufficient material is well-nigh

95. See note 265 infra and accompanying text. 
impossible to gather. Faced with such a problem, the judge who does not consult history may be ignoring the most important available source of information. As a source of understanding of the values which have shaped his society, an inquiry into history may always be relevant to a judge seeking to answer a question of values. In the right to counsel field, historical inquiry is more than usually relevant, for there is little precedent on the problem between 1791 and 1932. Though the Justices who first considered the right in modern times presented a review of that history, ${ }^{96}$ it is possible that more recent research ${ }^{97}$ may prove them mistaken. It is not necessary to seek in history an absolute value for counsel and to apply that value blindly to the modern situation - an approach which confuses eclecticism with valuable instruction. The Supreme Court has used historical analysis in the area of criminal procedure to gain a better understanding of modern problems. ${ }^{98}$ By following the lead of the Court it may be possible to find a guide to understanding the modern problem of counsel during interrogation.

\section{The History of Right to Counsel \\ The Common Lawe Right to Counsel}

The first mention in English law of persons serving the functions of counsel occurs in the Leges Henrici Primi, which Liebermann dates c. 1115:

De causis criminalibus uel capitalibus ... nemo quaerat consilium, quin inplacitatus statim perneget sine omni peticione consilii, ciuscumque nacionis uel condicionis sit: uel eius affirmacionem uel negacionem defensor aut dominus prosequatur competenti termino comprobandum..$^{00}$

Most authorities have cited this passage for the proposition that counsel has been denied in felony cases from the very beginning of English law. ${ }^{100}$ Certainly the first passage, with its phrase nemo quaerat consilium - let no man

96. There is also a review of the history in Powell v. Alabama, 287 U.S. 45, 60-65 (1932).

97. See, e.g., three articles of Heidelbaugh \& Becker, Benefit of Counsel in Criminal Cases in the Time of Coke, 6 Mranr L.Q. 546 (1952); Blackstone's Use of Mediaval Law in Criminal Cases Involving Benefit of Counsel, 7 id. 184 (1953); Right to Counsel in Criminal Cases, 28 Notre Dame Law, 351 (1953); Rackow, The Right to Counsel: English and American Precedents, 11 War. \& MARY QUART. 1 (3d ser. 1954).

98. See, e.g., Powell v. Alabama, 287 U.S. 45, 60-65 (1932); Boyd v. United States, 116 U.S. 616, 624-33 (1886).

99. 1 Itebermann, Gesetze der Angezsachsen 547, 571 (1903). Lex 47.

From the somewhat dubious Latin of the Leges the author of this Comment attempts a translation:

In criminal or capital cases let no man seek consilium; rather let him forthwith deny [the charge] without having pleaded [having impleaded?] [and] without any asking for consilium, of whatever nation or state of life he may be; [then] let his defendor or his lord follow up his affirmance [affirmative defense] or denial by the appropriate method of proof.

For Blackstone's freer and more fanciful translation, see 4 Blackstone, op. cit. supra note $90, * 355 \mathrm{n} .3$.

100. E.g., 1 Pollock \& Matrland, History of English Law 211-12 (2d ed. 1959). 
seek consilium - is suggestive of this interpretation. But such an interpretation may involve a misunderstanding of the word consilium. The consilium in Anglo-Saxon and early Norman procedure was not necessarily a man learned in the law who saw to it that the defendant's rights were not invaded; the term also referred to a motley crew of friends and relatives brought to the court to sway the judgment, to vouch for the accused, and to serve as witnesses or body-guards, as the case might require. ${ }^{101}$ That the accused was entitled to representation at trial in some respects is seen from the second part of this passage from the Leges, uel eius affirmacionem uel negacionem defensor aut dominus prosequatur competenti termino comprobandum, which may be translated as follows: "Let the accused's lord or defendor follow up his affirmance [affirmative defense?] or denial by the appropriate method of proof."

It is difficult to know exactly what is being forbidden the felony defendant since the author of the Leges is not precise in his words. It seems clear from other sources, however, that around the time of the Leges defendants commonly availed themselves of three modes of legal representation. The pleader, ${ }^{102}$ a man learned in the law who would handle the technicalities of pleading, provided professional advice as to the law. This man first appears in the Norman courts around the turn of the thirteenth century, where he is called the countour in Norman French or the narrator in Latin. Although the narrator was apparently unknown in the early Norman courts, another person, the placitator, ${ }^{103}$ seems to have filled the same function. The attornatus, ${ }^{104}$ who first appears in records around the time of Glanville (the end of the twelfth century) was a second source of legal assistance. This man is not a professional pleader, who helps a man in court, but an authorized deputy who appears in court in a man's stead; he is an attorney for that trial in the full sense of the word, but he is not a professional attorney as we would know him today. The third source of legal assistance ${ }^{105}$ was the advocatus or forespeca of AngloSaxon law, who was the surety or warranty for the accused. He was usually the man's lord and defended not on the defendant's behalf but on his own. Within this function we might include that of the defensor or champion in trial by combat and perhaps even in trial by the hundred.

Since there were so many kinds of legal assistance in the Middle Ages, all performed by different people, the use of the modern word "counsel" is inaccurate to describe any one of them. We might better look upon these various offices as types of representation analogous to modern counsel. Confusion is further generated because the term consilium is used at various places in the mediaeval texts to describe each of the particular kinds of legal assistance ${ }^{108}$

101. See Cohen, History of the English Bar 11, 13, 18 (1929).

102. See generally $i d$. at $59-62,169-82$.

103. Id. at $59-62$.

104. Id. at 127-43. See Prucknetr, op. cit. supra note 90, at 205-06.

105. CoHEN, op. cit. supra note 101, at $3,5,9,11,36$.

106. E.g., in the Leges 46,5 , it obviously refers to a pleader. 1 LIfBERManN, op. cit. supra note 99 , at $\mathbf{5 7 0}$. 
as well as to refer to the crowd of friends brought along to sway the moot in a more informal way. It seems that the passage in the Leges quoted above is best read as a reference to the latter. Before a man gets to plead and before he makes his defense, he must first deny the charge (inplacitatus perneget). After this let his defensor or his dominus follow the matter up (prosequatur) with the proof. Rather than denying the accused the opportunity for any assistance, the Leges would deny him only the opportunity to cook up an alibi with his friends or to wait until his accuser was without aid and intimidate him with a potent throng of consilium-a practice which apparently was common at the time in civil cases. ${ }^{107}$ What we find in this passage, then, is not a notion that the defendant should be without procedural safeguards, but that in criminal cases he should not be allowed to avail himself of extra-procedural safeguards.

In order to get some idea of how these various offices fitted into the mediaeval criminal process it is necessary to understand a little of mediaeval criminal procedure. We can give only the barest outlines of this procedure, with little hint as to its development from 1066 until 1485, the year of the accession of Henry Tudor. ${ }^{108}$ There were two basic methods of starting a criminal trial in the Middle Ages, indictment by a grand jury and the filing of a complaint, known as an appeal, by the injured party. The second procedure is said to be the less common, and it is true that Parliament discouraged and finally forbade it in minor cases. ${ }^{109}$ The Yearbooks of the fourteenth and fifteenth centuries indicate, however, that the felony appeal was by no means uncommon. ${ }^{110}$ On the other hand, the eyres, which were responsible for calling the grand juries, were held at infrequent intervals, ${ }^{111}$ though many indictments were returned when eyres were held. Thus, the appeal was a criminal proceeding more regularly available than the indictment. In the case of murder, at least, the appeal was the common and preferred method of proceeding.112 There are gaps in our knowledge as to exactly how the system worked. There were, for example, Commissions of Gaol Delivery ${ }^{113}$ which empowered justices to go about the counties two or three times a year and hear the cases of all who were in gaol. Those who were in gaol were those who had been caught red-handed either by the sheriff, by the justice of the peace or by private

107. See Leges, 49, 2(a), in LIEBERManN, op. cit. supra note 99, at 572.

108. See generally 1 Stephen, A History of the Crminal Law of England 244-72 (1883) [hereinafter cited as Stephen]; 3 Holdsworth, History of ENGlish LAW 607-20 (1936 ed.).

109. An Act Against Murderers, 1487, 3 Hen. 7, c. 2, demotes appeals from their preferred status since the parties had been slow in perfecting their appeals.

110. See, e.g., Anon., Y.B. 2 Edw. 2 (1309), p. 42 (Selden Soc. ed. 1903); Tayleur v. Asshyndon, 6 \& 7 Edw. 2 (1313), in 1 The EYre of Kent 113-14 (Selden Soc. ed. 1909); Athern v. Bigg, Y.B. 1 Hen. 6 (1422), pp. 1-10 (Selden Soc. ed. 1933).

111. 1 Stephen 103-04.

112. See note 109 supra and accompanying text.

113. 1 STEPHEN 105. 
parties ; it is unclear whether there was any need for an indictment if a man had been arrested.

Once a man was before the court, whether by indictment or appeal, the charge was read to him. ${ }^{114}$ In a trial under indictment, he was then called upon to plead to the charge, to challenge the jury, to challenge the indictment on legal grounds, or to plead autrefois acquit, autrefois convict, or pardon. He might also at this time make a plea of clergy. It appears that a more limited range of these initial pleas was customary in appeals cases. After the initial plea the two forms of trial appear to have had more similarities. The law permitted the pleading of exceptions to the indictment or the appeal, and, although pleading was not as complicated as the pleading to a civil complaint, it was around the pleading of these exceptions that the complexities of the criminal law arose. There was little presentation of evidence as we know it. 115 The earlier Middle Ages recognized the ordeal as a method for obtaining the truth, and, in appeals cases, trials by battle were the rule. In the felony indictment, however, the petit jury was used increasingly as a body of fact-finders. When the legal issues in the indictment had been defined, the judge would turn to the jury and, perhaps after brief argument by the parties, ask them to find on the factual issues raised. ${ }^{116}$

It is clear that the mediaeval courts permitted and even appointed a pleader in appeals cases. ${ }^{117}$ Thus at the most critical moment in the appeals trial, the pleading, the accused had assistance. It is less clear whether attorneys were permitted in appeals cases. Britton ${ }^{118}$ several times denies it though the language of the Statute of Westminster ${ }^{119}$ seems broad enough to include it. As to the defensor or the advocatus, it would seem that the role of this person in the literal sense - as the champion who fought the trial by battle - continued; all manner of people were involved in appeals suits, including widows, clerks and others who clearly could not themselves engage in trial by combat. ${ }^{120}$

None of the great mediaeval treatises on the common law specifically mention legal assistance in any form in the felony trial under indictment. From this it might be inferred that there was no assistance in these trials. But the contrary seems the better inference. Fortescue, in the mid-fifteenth century, says that

each of the parties, by themselves or their Counsel, ${ }^{121}$ in presence of the Court, shall declare and lay open to the Jury all and singular the matters

114. See generally id. at 297-301; 3 Holdsworth, op. cit. supra note 108, at $610-20$.

115. 1 STEPHeN 258-59.

116. See Hugo's case, Y.B. 30 \& 31 Edw. 1 (1303) reported in 1 StEphen 261-62.

117. See Saint Gernian, Doctor \& Student 256-59 (Mluchall ed. 1874); Stanford, Les Plees del Coron 151 (1560).

118. Britton, TrEatise 84 (Nichol's transl. 1901).

119. Statute of Westminster, the Second, 1285, 13 Edw. 1, c. 10.

120. E.g., Anon., Y.B. 2 Edw. 2 (1309), p. 42 (Selden Soc. ed. 1903); Tayleur v. Asshyndon, 6 \& 7 Edw. 2 (1313) in 1 The Eyre of KeNt 113-14 (Selden Soc. ed. 1909); BRITTON, op. cit. supra note 118, 91 n.1.

121. By this time the word was used in its modern sense meaning any kind of representation. 
and evidences, whereby they think they may be able to inform the Court concerning the truth of the point in question..$^{122}$

He does not mention felony cases on indictment as an exception to this rule. Besides, the mediaeval works are not altogether silent. The Mirror of Justices says :

[B] ecause folk do not generally know all the "exceptions" which can be used by way of answer, pleaders [countours] are necessary who know how to set forth causes and to defend them according to the rules of law and the usage of the realm, and they are the more necessary for the defence in indictments and appeals of felony than in venial causes. ${ }^{123}$

There are many points on which the Mirror is untrustworthy, but the points on which the author disagrees with his contemporaries are usually points of constitutional law, points of basic principle, while on matters of procedure he is most often reliable. ${ }^{124}$ The Yearbooks are unusually silent on the topic of counsel, though there is one case in which the accused is denied the opportunity to go out and bring in consilium in the old Anglo-Saxon fashion. ${ }^{125}$ On the other hand, we find in an appeal case of the late thirteenth century the appearance of "one Herle, apparently the first specialized criminal defense lawyer, who "defended all manner of felony, assault, waylaying and all that is against the King's peace, his crown and dignity."126

From these historical scraps we can draw some tentative conclusions as to the nature of representation in mediaeval criminal procedure. Though there was some feeling that a trial in which the interest of the state is involved should not be swayed by the pressure of a flock of the defendant's friends and that the defendant himself must be present and answer the charges, there were many places during appeals trials and some during indictment trials where he could receive legal assistance. The primary place in the trial at which he needed such assistance was at the pleading of exceptions. The presentation of the case as we know it was unknown then; witnesses do not appear at civil trials until the mid-fifteenth century, and the date of their appearance in criminal trials is uncertain. ${ }^{127}$

After presentation of factual evidence by witnesses became prevalent, sometime between the mid-fifteenth and sixteenth centuries, a curious distinction developed in the law of counsel. While the defendant might employ counsel in pleading matters of law, counsel could not assist in the demonstration of fact. It is unclear whether the restraint was present from the start, or developed some time after witnesses were introduced into the trial. Authors of the modern histories assume that the law of counsel of the late seventeenth century, that

122. Fortescue, Commendatron of the Laws of England 41 (Grigor transl. 1917).

123. Horn, The Mirror of Justices 90 (Selden Soc. ed. 1895).

124. See Introduction in $i d$. at ix-1v.

125. Hugo's Case, Y.B. 30 \& 31 Edw. 1 (1303) reported in 1 Strephen 261.

126. Anon., 2 Edw. 2 (1309), p. 42 (Selden Soc. ed. 1903).

127. 1 STEPHEN 263. 
counsel might be had for "questions of law" only, applied from the very beginning of the presentation of evidence. Yet the state trials of the fifteenth and early sixteenth century are sparse and the Yearbooks are silent on the topic. There is at least some basis for an inference that the introduction of witnesses preceded development of the rule. Stephen believed witnesses to have been introduced into criminal actions by the middle of the fifteenth century. ${ }^{128}$ Yet St. Germain, writing in the early sixteenth century, does not mention the rule denying counsel for matters of fact in felony trials, while Stanford, ${ }^{229}$ writing in the third quarter of the same century, does mention the rule. By the time of Coke the rule restricting counsel to matters of law is so well established that he does not seek to question that it has always been thus.

Dating the rule from the mid-sixteenth century makes some sense since that was the time the right to counsel was abolished in France ${ }^{130}$ and many Roman law procedures were introduced into England.131 Furthermore, it is difficult to understand how Fortescue and St. Germain could have ignored the rule, had it developed in the mid-fifteenth century. What seems especially persuasive for dating the rule after the introduction of witnesses is the distinction it draws between felony cases and misdemeanors: only in felony cases was counsel barred from assisting in the preparation of facts. ${ }^{132}$ Such a distinction is difficult to explain as deriving from the innovation in evidentiary practice; on the other hand, it may be reconciled with a notion that the felony defendant was not to be protected since he posed a greater danger to the state. Sir John Hawles, Solicitor-General of England at the end of the seventeenth century, describes the development of the doctrine in a manner suggesting the correctness of this analysis. He finds the rule's source in mistaken judicial practice which after long use had attained the "colour of a law."133

In the presence of the mediaeval doctrine denying the defendant consilium and at the same time allowing him a pleader, it is easy to see how the fragmentation of consilium into what we now know as witnesses, jurors, and bondsmen resulted in confusion as to the meaning of the early rule against

128. Id. at 264-65.

129. Stanford, op. cit. sulpra note 117 , at 151. Stanford's chapter on evidence, id. at 163-64, does not make it clear whether the defendant could put forward any evidence. Counsel, Stanford says, should be denied on pleas of not guilty because the defendant knows the facts better than counsel and presentation of the facts by counsel would confuse the issues with learning. He mentions, however, that counsel may appear as amicus curiae to inform the court that it errs in a question of law and also that the defendant may have counsel to argue special pleas, such as a plea of sanctuary.

130. See Rackow, supra note 97, at 1 \& n.1; Ploscowe, The Development of PresentDay Criminal Procedures in Europe and America, 48 HARv. L. REv. 433, 449-52 (1935).

131. See Ploscowe, supra note 130; Pound, The Future of the Criminal Law, 21

Colum. L. Rev. (1921) ; 9 HoldswortH, History of English Law 223-29 (1922 ed.).

132. 4 Blacrstone, Commentaries *355 (1899). See Rosewell's Case, 3 State Trials 909, 968 (2d ed. 1730) [hereinafter cited as St. Tr.] (statement of Lord Jeffreys). 133. 4 St. Tr. $165,174$. 
consilium. Since what was finally left of the consilium became the modern counsel, ${ }^{134}$ the rule could easily have been interpreted to mean that legal assistance was to be denied the defendant. There was, however, a check on this tendency in the rule that the accused could employ the assistance of a pleader. Thus in the old legal questions, those of pleading, the accused could still have legal assistance, but he was denied such assistance at the newer part of the trial, the presentation of evidence, because of a misunderstanding of the general protective function of consilium. Such a misunderstanding could have arisen in the practice of individual trial judges ${ }^{135}$ and could have achieved the status of an absolute rule as the pressure towards maximizing the state's interests became greater as the sixteenth century moved on.

Whatever its origin, by the time of Coke the rule was that the accused must plead to the indictment and make his defense as to the facts without the aid of counsel. In matters of law, however, the defendant might use counsel to aid him. ${ }^{136}$ Coke gives two reasons why the accused may not have counsel for matters of fact:

First, that the testimonies and the proofs of the offense ought to be so clear and manifest, as there can be no defense of it. Secondly, the court ought to be in stead of councell for the prisoner, to see that nothing be urged against him contrary to law and right; nay, any learned man that is present may inform the court for the benefit of the prisoner. . . 137

Later he adds a third reason:

Where any person is indicted of treason or felony, and pleadeth to the treason or felony, not guilty, which goeth to the fact best known to the party; it is holden that the party in that case shall have no councell to give in evidence, or alleage any matter for him; but for as much as ex facto jus oritur it is necessary to be explained, what matters upon his arraignment, or after not guilty pleaded, he may alleage for his defence, and pray councell learned to utter the same in forme of law. ${ }^{138}$

In a system in which the presentation of proof was highly informal, this division might well not be thought too prejudicial to the defendant. The defendant presents the facts peculiarly within his knowledge, and his counsel pleads the law, arguing how it applies to the facts. Coke has a notion that anything that the defendant can present to negate the prosecution's case should be sufficient to acquit, so that the defense case need not be presented with much art,

134. Attornatus is not the ancestor of modern counsel since attornatus did not become professionalized. See generally CoHEN, op. cit. supra note 101, at 126-43.

135. E.g., Anon., Y.B. Pasch. 9 Edw. 4, f.2, pl. 4, (1496), the first, so far as the author knows, mention of the rule, in a note in an appeals case: "Et nota, $q$ le def. en enditement de felony n'avera counsel vers le Roy s'il me soit natter en ley: Mes en appeal auter est, \&c."

136. On Coke's passages about counsel see Heidelbaugh \& Becker, Bencfit by Counsel in Criminal Cases in the Time of Coke, 6 MIANI L.Q. 546 (1952). It is interesting to compare Coke's passage with Stanford's, supra note 129, for Coke seems to draw much from Stanford's compressed account.

137. 3 CoKe, Institutes 29 (1817) [hereinafter cited as Coke].

138. 3 CoKE 136. The tag means "law rises out of fact." 
and, secondly, Coke pictures the judge as an impartial figure who sees that everything is done according to law. These two reasons are not true rationales but rather excuses which tend to show that the system can be made tolerable for the defendant by the presence of other checks in his favor.

It is questionable whether even in Coke's time the system offered sufficient protections to the defendant. Coke itemizes six kinds of arguments which counsel ought to be allowed to make: that the indictment does not allege facts which constitute a crime under the law; that a statute has been misapplied or has fallen into desuetude; that the indictment was not drawn upon suffcient evidence; that the indictment is fatal for vagueness or that the act alleged has been pardoned; that the state's case is not proved by the requisite number of witnesses; and that the court has no jurisdiction. The burden seems to be on the defendant to raise questions of law before he can have counsel: "For it is to be observed, that in no case the party arraigned of treason or felony, can pray councell learned generally, but must shew some cause."139 On the other hand this sentence may simply refer to the assignment of counsel and to the granting of permission for the counsel to argue the matter before the court. Later Coke says, "And that the prisoner may alleage these or the like matters, it is evident, because for every matter in law rising upon the fact, the prisoner shall have councell learned assigned to him."140 There is nothing in Coke to lead us to believe that the accused might not bring his counsel into Court and have him ready should any questions of law arise, and indeed he says, "Also it is lawfull for any man that is in court, to informe the court of any of these matters, lest the court should erre, and the prisoner unjustly for his life proceeded with." 141 Coke's picture of the function of counsel, then, shows that he does not conceive of a trial without counsel, such as Betts had, but a trial in which counsel's role was limited to the presentation of arguments of law. Ostensibly, this is the rule which is followed until the middle of the eighteenth century. There was, however, great variety in the practice of these hundred and fifty years, a variety founded on a confusion about what are matters of law and what matters of fact.

The system which we see described in Coke is certainly no improvement over the mediaeval one from the point of view of the defendant; on the other hand, it is not grossly overbalanced on the side of the state. In Coke's time, his excuses may have carried some weight. Whatever the standard of judicial impartiality in Coke's day and whatever may have been the quantum of proof necessary for conviction, however, these checks rapidly declined in the years following Coke's death. In their absence the fact-law distinction became a method for forcing men on trial for their lives to stand alone against the state. The difficulty with Coke's system was that the rights of the defendant were not sufficiently secured in law; they were too vague to withstand the

139. Ibid.

140. Id. at 137.

141. Ibid. 
hysterical pressures which the treason trials of the seventeenth century brought to bear on them. The denial of counsel as to matters of fact and the haziness of the distinction between matters of fact and matters of law contributed to this most appalling chapter in the history of English criminal law. Full accounts of the state trials of the seventeenth century have been written elsewhere and so much invective has been poured out upon the procedures by which they were conducted that it seems of little use to rehearse either the accounts or the invective. ${ }^{142}$ Let us simply point out how the right to counsel is cramped and confined from what it was in Coke's day until it almost disappears.

In Raleigh's Case (1603) ${ }^{143}$ Lord Coke himself was party to a proceeding in which the court, rather than being counsel for the prisoner, abused him in the most violent language, and did not assign him counsel to argue the statutory question of whether the two-witness requirement had been met. In Lilburne's Case (1649) ${ }^{144}$ the accused asked for counsel to challenge the indictment on the grounds that it had not been properly found by the court of oyer and terminer which also was trying him. The court refused to grant him counsel on the ground that the question was not one of law. In Love's Case (1651) ${ }^{145}$ the defendant wished to have counsel for challenging the indictment but was forced to plead first. Such a practice is not envisaged by Coke, who said the challenges to the indictment must come before the plea. In the trial of Viscount Stafford $(1680)^{146}$ the defendant was denied counsel to argue the point that treasonable acts must be proven by two witnesses. This is in direct violation of Coke's fifth exception. In Fitz-Harris' Case (1681) ${ }^{\mathbf{1 4 7}}$ and Colledge's Case $(1681)^{148}$ the defendants were not allowed to make use of papers which had been prepared by their counsel before the trial began. In the latter case, the papers - which contained Colledge's defense - were seized by the prosecution before the trial and used to the state's advantage. In Russel's Case $(1683)^{149}$ the defendant was denied counsel first on the question of whether hearsay was admissible and once again on whether the statute under which he was being tried covered the acts alleged. On the first matter, the court said that it was a question of fact and not of law; as to the second, it held that the accused would have to admit the fact before the applicability of the law could be called into question. Here is a clear violation of Coke's second exception. This strict attitude survived the accession to the throne of William and Mary. In the trial of Ashton and Elliot ${ }^{150}$ for treason, Ashton was denied

142. For the former see 1 StEPHEN 319-428; for the latter see Douglas, $A$ Challinge to the Bar, 28 Notre Dame Law. 497 (1953).

143. 1 St. Tr. 205 (1603).

144. 2 St. Tr. 19, 35-36, 39 (1649).

145. 2 St. Tr. $83,87-88$ (1651).

146. 3 St. Tr. 102, 122, 208 (1680).

147. 3 St. Tr. 261, 261-62 (1681)

148. 3 St. Tr. $342,343-52$ (1681). See 4 St. Tr. at 174-76 (Hawles' remarks on this proceeding).

149. 3 St. Tr. $629,629-30,645$ (1683).

150. 4 St. Tr. 409,416 (1690). 
counsel to debate the point of whether he might see a copy of the indictment; in Parkyn' Case (1695) ${ }^{151}$ the defendant was denied counsel although the act of Parliament permitting it was to go into effect the next day. Concerning the theory that the court was counsel for the accused, the last words of Lady Alice Lisle are perhaps the best commentary:

I have been told, the Court ought to be Counsel for the Prisoner, instead of which, there was Evidence given from thence; which, though it were but Hearsay, might possibly affect my Jury. My Defence was such as might be expected from a weak Woman; but such as it was, I did not hear it repeated again to the Jury. ${ }^{152}$

In 1695 Parliament passed the celebrated act "for regulating of trials in cases of treason and misprison of treason."153 This act provided, among other things, that the accused was to have counsel in cases of treason for both matters of law and fact and that if he could not afford counsel, the court was to appoint it for him. The effect of this act may be seen in the trial of Charles Cranburne (1696), ${ }^{\mathbf{1 5 4}}$ in which counsel made many objections to the indictment and conducted a vigorous cross-examination of the state's witnesses. Although this act applied only to trials for treason, it betokened an eighteenth century trend toward mollification of the rigors of the seventeenth century felony rule. Thus, in the trial of Captain Kidd (1701) ${ }^{155}$ the defendant had counsel assigned to him only for matters of law, but the assignment was made just after he had pleaded. By the middle of the eighteenth century a rule seems to have arisen by which "questions of law" were extended to include both direct and cross-examination. The origin of this rule seems to have been in the notion that counsel could examine witnesses on what was regarded as a collateral issue. Thus on the trial of a collateral issue, Ratcliffe $(1746)^{\mathbf{1 5 6}}$ had counsel who both cross-examined the King's witnesses and observed fully upon the evidence. Lovat's Case (1747) ${ }^{157}$ is the last major case in which the court did not allow counsel to examine witnesses. In the trials of Mary Blandy (1752), ${ }^{168}$ John Barbot (1753), ${ }^{159}$ and William Barnard (1758) ${ }^{160}$ counsel for the defendants were allowed to examine the witnesses, though in the trial of Barbot the defendant had to protest vigorously before counsel was allowed at all ; once counsel was in, the judge's interpretation of "points of law" seemed to include the questioning of witnesses. It was not until 1836 that all distinctions between facts and law were abolished by statute and a full defense

151. 4 St. Tr. 615, 618-19 (1695).

152. 4 St. Tr. 117,130 (1685).

153. The Treason Act, 1695, 7 \& 8 Will. 3, c. 3.

154. 4 St. Tr. 686 (1696).

155. 5 St. Tr. 287, 287-s8 (1701).

156. 18 State Trials 430, 434-35 (1746) (Howell ed. 1816) [hereinafter cited as How. St. Tr.].

157. 18 How. St. Tr. 529, 578-79 (1747).

158. 18 How. St. Tr. 1118 (1752).

159. 18 How. St. Tr. 1230, 1231 (1753).

160. 19 How. St. Tr. 815, 826, 828-31 (1758). 
was guaranteed to all accused of felony. ${ }^{161}$ It would seem, however, that this act was but legislative confirmation of what had been the best judicial practice for almost 75 years.

What is especially significant about the common law of counsel is the appearance of some sort of right to counsel during the pre-trial period. In modern trials, the right to counsel has been extended back on the grounds that early consultation is needed to develop adequate defenses during the trial stage of the proceeding. ${ }^{162}$ But in an earlier system, when counsel's role at trial was confined to matters of law, it might be expected that pre-trial preparation and consultation would be seriously limited. Surprisingly, even in the 1680's counsel was regularly allowed to see the prisoner in advance of trial. Lord William Russel had counsel while he was in the Tower. ${ }^{163}$ Even Colledge and Fitz-Harris must have had counsel while in prison, else the problem of their using papers drawn up by counsel never would have arisen. ${ }^{104}$ Sir John Hawles, expressing his disapproval that Colledge and Fitz-Harris in the Plot trials had their papers seized, states that not only was the prisoner regularly allowed to see counsel but that he also was allowed to see his friends and hire a solicitor to investigate the factual side of his case. ${ }^{165}$ It is hard to say whether such consultation was a matter of right or a matter of grace on the part of the gaoler. In Love's Case the court thought it necessary to order the gaoler to grant Love's counsel access to him at all seasonable times, and after the passage of the Treason Act of 1695 similar orders were issued allowing the prisoner access to counsel and friends. ${ }^{167}$ On the one hand, such orders may be the first evidence of judicial reaction to a traditional gaoler practice of denying prisoners access to counsel; on the other, they may be a judicial enforcement of long-standing practices against newly recalcitrant gaolers. It is unfortunate that treason cases are the only ones which deal specifically with this problem since there seems to have been a strict doctrine making anyone who aided a man charged with treason also liable to punishment for treason. ${ }^{108}$ But Hawles' argument that this doctrine should not apply to legal advice indicates that gaolers in the normal run of cases permitted early consultation.

From the treason cases as well as from other evidence another facet of the general availability of counsel emerges. Like the implication in Gideon some 400 years later, there was no distinction at common law between retained and appointed counsel. ${ }^{169}$ Whether or not a man should have counsel depended not on ability to pay, but on whether a point of law arose. In treason

161. Trials for Felony Act, 1836, 687 Will. 4, c. 114, § 1 .

162. See note 30 supra and accompanying text.

163. 3 St. Tr. 629, 630 (1683).

164. See 4 St. Tr. at 174 (Hawles' remarks).

165. Id. at 174-75.

167. See Rookwood's Case 4 St. Tr. 649, 650 (1696) ; Ratcliffe's Case 9 St. Tr. 582

(1746) ; Lovat's Case 18 How. St. Tr. 529, 532 (1747).

168. 4 St. Tr. at 174-75.

169. See text at note 140 supra for Coke's use of "assignment." 
cases, counsel was always described as "assigned" counsel. By this device he could avoid the taint of "treason by association": he was serving the court, not the prisoner. Of course, what is referred to as "assigned" counsel, in some cases quite obviously had been previously retained and were simply waiting for the formality of appointment; at other times, however, it appears as if the defendant came into court without counsel and the court assigned counsel from the members of the bar present. ${ }^{170}$ Hawles says that the rule denying all prisoners charged with a felony the right to counsel arose because so many poverty-striken felony defendants appeared without counsel. ${ }^{171} \mathrm{His}$ assumptions about the past role of appointed counsel are questionable; periodic references are made in even the earliest cases to assignment of counsel. And the form of his statement at least suggests that he could not conceive of a situation in which the size of a man's purse governed whether he had counsel or not. Furthermore, Hawles was reflecting on conditions in criminal cases prior to his time. By the middle of the eighteenth century the courts clearly were appointing counsel for indigent and unpopular ${ }^{172}$ defendants. In the trial of McDaniel (1755) ${ }^{173}$ counsel prefaced his argument by saying: ". . . I could not have been prevailed upon to have been counsel for such a set of rogues, had I not been appointed by your lordships." Like the allowing of counsel in felony cases for matters of fact, the appointment of counsel did not become a matter of legislative concern until long after it became a judicial practice. ${ }^{174}$ The early practice of assigning counsel seems to indicate that in the limited area in which the courts were allowing counsel at all, counsel was a right, not merely a privilege, and that it was the duty of the court to see that a man got counsel, at least for legal questions.

This brief history of the right to counsel in English common law is significant in its revelation of a much richer and older law of counsel than Justice Roberts would have us believe existed. Such a short account, however, invariably raises difficult questions concerning the basic nature of the early English criminal proceeding, questions which cannot be answered here. One might make quite a valid objection to any criminal law history which relies

170. Compare Kidd's Case 5 St. Tr. 287, 287-88 (1701), with Sidney's Case 3 St. Tr. 710, 738 (1683) and Love's Case 2 St. Tr. 83, 88 (1651).

171. 4 St. Tr. at 174.

172. See Beanex, The Right to Counser in American Courts 10 (1955).

173. 19 How. St. Tr. 745, 790 (1755).

174. The Poor Prisoners' Defence Act, 1903, 3 Edw. 7, c. 38, § 1, authorized the appointment of counsel in cases where justice required it. This act simply confirmed the existing practice and may even have had the effect of limiting the appointment of counsel. The Poor Prisoners' Defence Act, 1930, 20 \& 21 Geo. 5, c. 32, § 1(3) (a), made the appointment mandatory for murder; this act, too, proved unsatisfactory since the judges seemed to act in adherence more to the letter of the law than to its spirit. The Legal Aid and Advice Act, 1949, 12 \& 13 Geo. 6, c. 51, modified the previous acts somewhat but it may be said that at this date the appointment of counsel in felony cases is not as certain in England as it is in the United States since Gideon. See BEANEY, op. cit. supra note 172 , at $12-14$. 
heavily on the state trials, the causes célíbres of the day, as examples. The defense to this methodological charge is one of necessity - the state trials are the only full trial records surviving from the time, and they give a better picture of the criminal process than no records at all. Then too, it may be a mistake to say that since famous men were involved in these trials, one must assume that the average felon got even less of a hearing. We have often seen how the notoriety of a case may result in a lack of consideration of procedural safeguards $;^{175}$ it is possible that where public opinion was less involved and where the interest of the state was less at stake, there was more consideration paid to the person of the defendant. This opinion is reinforced by Sir John Hawles' writings on the trials of the Popish Plot; he attacks the refusal to allow some defendants to see their lawyers as contrary to the usual practice in a felony case. ${ }^{176}$

\section{The Right to Counsel in the American Colonies}

The variety in the colonial statutes and provisions on the right to counsel (see the Appendix) might suggest that the colonists did not regard the right as fundamental. On balance, however, the inference seems a dubious one. In England, the right was judicially enforced; except for the treason statute there were no English statutory provisions regarding counsel until 1836. Assuming the colonies to have followed the same pattern, it would be impossible to tell how much real variation there was between the colonies in the absence of a thorough study of the practice in the colonial courts. Then too, this was a time of flux in the right to counsel in England itself. The old distinction between facts and law was being abolished and courts were showing some tendency to appoint counsel for the undefended for the entire period of the trial rather than just for specific points of law. ${ }^{\mathbf{1 7 7}}$ Some clues are available, moreover, from the colonial legislation. Connecticut (17??), Pennsylvania (1718), Delaware (1719), South Carolina (1731), and perhaps New York (1777) all had provisions requiring the appointment of counsel in felony cases. ${ }^{178}$ By 1789 , the year in which the sixth amendment was proposed in Congress, every state except Rhode Island and Georgia had some provision regarding the right to counsel. The wording of the provisions seems to differ according to geographical area, but eleven of the states had either directly or impliedly abolished the fact-law distinction :178 New Hampshire, Vermont, and Massachusetts word it in terms of a "full hearing"; New York in terms of allowance of counsel "as in civil actions"; Delaware, Pennsylvania and New Jersey in terms of giving the defendant the same right to counsel as his prosecutor; North Carolina specifically grants the

175. See Sauvage, The Oswald Affair, Commentary, Mar. 1964, p. 55; 1 StepHeN at 345 .

176. 4 St. Tr. at 174.

177. See BEANEY, op. cit. supra note 172, at 22-24.

178. See Appendix.

179. See Appendix. 
right "as well as to facts as to law" and, according to Swift, Connecticut had the same provisions; South Carolina speaks of a "full defense" by counsel. By $1800 \mathrm{New}$ Jersey had included a right to appointed counsel in its constitution, Rhode Island had passed a statute similar to the sixth amendment, and Georgia had a provision allowing counsel to advocate or defend the cause of an accused. One need not assume that when these provisions were enacted that they represented a great innovation in actual judicial practice of the state.

It was against this background that the sixth amendment was adopted. Virginia, which never had a guaranty of right to counsel in its own constitution, was the first state to propose the right for inclusion in a federal bill of rights. North Carolina also had the provision in its suggested bill, and New York included it in the assumed rights upon which it conditionally ratified the Constitution. Madison proposed the present sixth amendment in the House on July 2, 1789, and it passed both Houses almost without debate. It was ratified in late $1791 .{ }^{180}$ The Framers seem to have intended it to be an assurance that rights would not be denied again during a period of judicial hysteria as they had been in seventeenth century England.

From 1791 until 1932 state and federal courts saw practically no cases on the right to counsel. ${ }^{181}$ At the turn of the century as American society became more urbanized, the problem of the indigent and friendless defendant came more and more before the courts. The state courts developed various uniform policies to replace the helter-skelter of individual decisions in the area, some of which policies were not calculated to see that the indigent were well represented. ${ }^{182}$ In the 'twenties with the increasing national awareness of crime, a public callousness to the defendant's rights developed;183 that it arose may suggest an insufficient realization that the first to suffer from a diminution of rights is not the professional gangster but the casual criminal or the innocent. Within this setting the Scotsboro Cases came to the national attention and prompted the Supreme Court's awakening to the issue of counsel in Pozell v. Alabama. ${ }^{184}$

\section{The History Summarized}

These, then, are the random incidents providing the historical basis for a contemporary meaning for the right to counsel. What remains is the need to

180. For the legislative history of the sixth amendment see Rackow, The Right to Counscl: English and American Precedents, 11 WM. \& MARY QuART. 1, 21-26 (3d ser. 1954) and authorities cited therein.

181. There is the famous dictum of Justice Brown in Holden v. Hardy, 169 U.S. 366, 386 (1898), pointing out how much better American procedure is than English concerning the right to counsel, and there is the case of Andersen v. Treat, 172 U.S. 24 (1898), in which the Court approved the appointment of counsel by the lower court in a complex case involving conflict of interest. See also Taney, C.J., in United States v. Reid, 53 U.S. (12 How.) 361, 364 (1851).

182. See BEANEY, op. cit. supra note 172 , at $80-94$.

183. See Pound, supra note 131, at 13-14.

184. 287 U.S. 45 (1932). 
integrate the experience of the past into the problems of the present. If, in some sense, the "nature" of the right to counsel can be understood, its application in new contexts can be determined. One thing can be said with certainty: the right to counsel was, at least in some form, one of the basic and continuing procedural rights of criminal defendants in the common law. Not until the sixteenth century, when many foreign elements were introduced into the criminal procedure of England and absolutist notions of the state came into vogue, was the right to counsel kept from expanding, by the factslaw distinction. Even then, it was always understood that the right to counsel, within its limited range, was absolute. In the middle of the most restrictive period Sir Francis Winnington could say: "This Lord being accused of High-Treason, the allowing of Council is not a matter of discretion. If matters of law arise, all our books say that Council ought to be allowed . . ."185 Another lesson equally important is that when the right to counsel was not expanded to meet the increased scope of trial, fundamental unfairness to the accused resulted. Lord Russel and Lady Alice Lisle were convicted on hearsay. In the trial of Langhorn for treason, the testimony of Titus Oates could have been destroyed by any skillful cross-examination. This is a particularly striking example of the absolute necessity. of counsel, for Langhorn was himself a barrister. ${ }^{186}$

What is particularly striking in this development is the manner in which the extent of the right to counsel fluctuates. It is commonly assumed that throughout history there has been a trend toward giving the defendant more rights, taking more and more power from the state. Under this theory, society has been able to afford its dispensation because the state has become increasingly powerful and its position less precarious. ${ }^{187}$ Underlying the theory is the caveat that if individual rights outrun the increasing stability of the state, society would be swamped by a wave of crime. If the records of the seventeenth century state trials are compared with any modern criminal record, the hypothesis is vindicated. But one swallow does not a summer make: the history of a trend is falsified by relying on so drastic and simple a juxtaposition. In fact, the measure of the right to counsel has not been the amount of power a given society can "afford to grant." The rights of the defendant seem to run in cycles not according to the amount of power the government actually has but the amount it wants to have. ${ }^{188}$

The right to counsel, then, is not a recent grant of largess by society but an old right which has never completely faded in the face of severe opposition.

185. Stafford's Case, 3 St. Tr. 101, 122 (1680).

186. 2 St. Tr. 874 (1679). Langhorn, for example, failed to cross-examine Oates on the arrangement of his chambers when such cross-examination would have proven that Oates had never seen the chambers. Once again the adage was proven, "He who defends himself has a fool for a client and an ass for a lawyer."

187. See generally 1 Stephen 354-57; 3 Holdsworte, History of English Law 607-23 (1936 ed.) ; Heidelbaugh \& Becker, supra note 136, at 547.

188. To the same effect see Pound, supra note 131, at 9-10. 
Records of persons serving counsel's function occur at an early date. As the state's concern for its power increased in Tudor times and as evidence was introduced into criminal trials, there arose the notion that one could have assistance only for the technicalities and not for matters of fact. This notion became more and more dominant until in the time of the Stuarts, matters of law were defined so narrowly that the accused stood against the state practically without aid. When the state's concern for its power declined during the Hanoverian times, and England was ruled by the dual theories of "quieta non movere" and "every man has his price," the right to counsel was revived, the facts-law distinction was virtually abandoned, and extensive appointments of counsel were made for the indigent. This pattern is reflected in the United States also; the right was formulated by the weak colonial governments, ran its gravest risk of extinction during the crime wave of the 'twenties, was revived by the Supreme Court in the 'thirties, and has been most stringently applied during the crime wave of the 'fifties and early 'sixties.

There is yet another myth concerning the growth of the right to counsel: that increased use of counsel has been sparked only by the rising complexity of trials, the proliferation of the rules of evidence, and the complicating factors of mens rea and the insanity defense. ${ }^{189}$ In the early English procedure, when there was no presentation of evidence and the essential points in the process in which the individual stood up against his accusers were the pleading, the argument, and the trial by battle, the accused, as far as we can see, was allowed to have counsel for all three critical points. It was not until the sixteenth century that there developed a notion that counsel need not be present for all the critical points of confrontation in the trial process. The avowed purpose of the facts-law distinction, which saw its most restrictive elaboration then, was to divide technicalities of law from matters of fact and to give the accused the aid of counsel only for the former - the sole aspect in which it was thought that he needed it. The rule proved highly unsatisfactory; it was discovered that the defendant's technical incompetence was not the only reason why he could not conduct his own defense, and that under the pressure of trial the defendant was simply incapable of conducting any defense. This restricted notion of counsel was not the one which the colonists adopted in the United States. Though the colonial provisions about counsel were in accord on few things, they agreed on the necessity of abolishing the facts-law distinction; ${ }^{190}$ the colonists appreciated that if a defendant were forced to stand alone against the state, his case was

189. Cf. Powell v. Alabama, 287 U.S. 45, $68-69$ (1932) ; Johnson v. Zerbst, 304 U.S. $458,462-66$ (1938) :

[The Sixth Amendment] embodies a realistic recognition of the obvious truth that the average defendant does not have the professional skill to protect himself when brought before a tribunal with power to take his life or liberty .... That which is simple, orderly and necessary to the lawyer, to the untrained layman may appear intricate, complex and mysterious.

190. See text at notes 178-79 supra. 
foredoomed. The introduction of evidence into the criminal trial had created a new point of confrontation between the state and the individual, and under an adversary system of criminal justice, the accused must have the buffer of counsel between himself and the force of the state at all such points. Indeed counsel at trial may be said to have been the cause of the complicating factors. The hearsay rule was known only in its crudest form until the late eighteenth century; the thirty-one exceptions ${ }^{191}$ are products of the nineteenth and twentieth centuries. ${ }^{192}$ The $M^{\prime}$ Naughton rule, ${ }^{193}$ the first rational statement of the insanity defense, comes in the early nineteenth century. Until we have counsel present at a particular stage in the criminal process the effective formulation of legal rules is impossible; the presence of counsel in the trials of the middle and late eighteenth century made the reforms of the early nineteenth century possible.

\section{The Investigative Process}

Counsel, then, has been more than a technical aid; he has served to overcome the original unfairness of the balance of state against individual. Historically, this role has been played mainly at trial - the focus of confrontation. If, however, a critical confrontation occurs at the earlier investigative stage of the process, we might have to alter our conception of the role counsel must play to readjust the balance.

Criminal investigation by the police, with its concomitant of police interrogation, is a product of the late nineteenth century. ${ }^{194}$ This does not mean that in the past no crimes were investigated or that no one was interrogated, but investigation was not a function of the police. ${ }^{195}$ There have always been police of one sort or another, but they were charged with guarding against crime and arresting known offenders and not with the ferreting out of offenders. ${ }^{196}$ In mediaeval England there were a few constables in every parish and watchmen in every town. These men were not expected to do the guarding by themselves; every man was required by law to keep arms ${ }^{197}$ so that when the constable or watchman raised the hue and cry, the discovered criminal might be pursued. Though peace officers might arrest any man whom they suspected on reasonable grounds of having committed a felony, this power does not seem to have been exercised nearly so frequently as their power to arrest for a felony if it had been committed in their presence or to arrest for a misdemeanor which was committed in their presence and which in-

191. So enumerated in the Uniform Rules of Evidence.

192. See 5 Wigmore, Evidence $\$$ 1420-27 (9th ed. 1940).

193. M'Naughton's Case, 8 Eng. Rep. 718 (1843).

194. See note 235 infra and accompanying text.

195. See Howard, Criminal Justice in England 581-83 (1931).

196. See 1 Radzinowicz, History of English Crininal Law 28-31 (1948); 1 Stephen 194-96; Mattland, Justice and Police 105-08 (1885).

197. Assize of Arms (1181), in Stubes, Select Charters 153-56 (1874). 
volved a breach of the peace. They had no investigative resources ${ }^{198}$ and were subject to suit for false arrest should they make a mistake. Further, unlike our modern police, the constables were neither very effective nor very powerful. The history of the constables and watchmen is one of decay, ${ }^{109}$ and by the end of the eighteenth century with the rise of such great cities as London, the mediaeval system of watchmen had become a national disgrace..$^{200}$

If the police were not charged with the investigation of crime until the end of the nineteenth century, it might well be asked who did investigate crime. Until relatively modern times the investigator of crime was basically a private function, though there were some occasions when the state became involved. In mediaeval England the preservation of the King's peace and the investigation of crime were the joint responsibility of all the citizenry. Each citizen was required to keep arms on hand so that he might aid in the pursuit of known criminals, and bystanders were required to aid a peace officer in making an arrest. The King saw to it that his criminal law was enforced ${ }^{201}$ through his justices who at irregular intervals called twelve men from the county (hundred) and four men from each city (borough) to present the justices with information concerning the commission of crime in the area since the justices had last been there. It is not known whether this group, the ancestor of the grand jury, conducted investigations, examining witnesses before them and hearing evidence, or whether they simply made their presentments or indictments on the basis of common knowledge and community investigation of the crime. Since the very complete records surviving from the Eyre of Kent (1314-15) make no mention of investigation by grand juries at the time of presentment, the better inference is that the investigations were conducted informally, before the eyre was convened. Crime detecting functions appear also to have been filled by individual citizens who, if they had been injured by a crime, had the power to prosecute the criminal by way of appeal. Since appeal and indictment were the principal means of introducing persons into the criminal process, it may be said that originally the investigation of crime was almost exclusively private. Interrogation could be conducted only with those who were willing to be interrogated, and the essential point of confrontation would be at the trial, in which twelve members of the community who had not been on the grand jury would check the sufficiency of the charge against the accused. ${ }^{202}$

198. Cf. 1 STEPHEN 196.

199. Dogberry is not a gross exaggeration of what the office was like in Shakespeare's day. See Much Ado About Nothing, in Shakespeare's Works (Craig ed. 1951).

200. The eighteenth century constables were so poorly paid that only old men could afford to take the job, and though the number and size of the cities had increased enormously, there were no provisions made for an increase in the number of watchmen. See generally Colguhoun, ON the Poltce of the Metropolis (1796). It was not until the second quarter of the nineteenth century that anything like a modern police force arose charged with the investigation of crime in the name of the state. See note 235 infra and accompanying text.

201. See Introduction in 1 The Eyre of Kent xlvii-xlix (Selden Soc. ed. 1909).

202. Ibid. 
The state attempted at various times to become involved in criminal investigation. Some of the methods of investigation it adopted were surrounded with safeguards and became part of our judicial criminal process, others were more informal and led to something like interrogation in the sense of a confrontation between the state and the accused in which the state tries to obtain confessions or admissions. In the middle of the thirteenth century the coroner's inquest, first described in Bracton, was instituted. ${ }^{203}$ Like the grand jury, the coroner's jury was composed of twelve men from the hundred and four from each borough, but, unlike the grand jury, there seems to be little doubt that the coroner's jury heard evidence. Convened immediately upon report of a death under suspicious circumstances, it sought first to determine whether a crime had been committed and then to find out who had committed it. Murder was thought to be too important to leave in private hands until the eyre or the justices' coming for Gaol Delivery. The coroner's jury, composed of laymen and a minor official, however, never really used interrogation; the process was surrounded with too many safeguards. From the very beginning the process seems to have been a public one and thus open to outside control.

Investigation by the Privy Council was another method of public inquiry into criminal activity ${ }^{204}$ it also arose in the thirteenth century. The council investigated cases of great national importance and cases in which it seemed likely that the ordinary process of justice would be subverted by the importance of the men involved. The Council initiated English use of state-oriented methods of investigation, drawn from the Roman law, ${ }^{205}$ which were becoming popular on the Continent at the time and which in many ways resembled modern police interrogative techniques. The witness was questioned in secret, without the benefit of counsel; he was given no inkling of whether he was being charged with a crime or who was charging him of what; unlike modern interrogation, the witness was also put under oath and required to answer the questions. Interrogation by the Council was open to such great abuse, that it was suppressed by the petition of Parliament in $1350 .{ }^{200}$ That it does not seem to have died out entirely may be seen by the occasional complaints which Parliament makes in the succeeding years that the Council is hearing criminal cases, "non par proces de ley de ceo en arere use."207 The important thing about these complaints is not that they indicate that this extraordinary process was still going on before the Council, but that, though Parliament

203. 3 BRACTON 342-45 (Woodbine ed. 1915). See Statute de Officio Coronatoris, 1276, 4 Edw. 1, c. 2; 1 STEPHEN 216-19.

204. 1 STEPHEN 166-84.

205. See Introduction, in Select Cases before the King's Councir 1243-1482, xiixiii (Selden Soc. ed. 1918).

206. 1 STEPHEN 166-83.

207. "Not according to the former usage of law." Author's transl. See 1 STEPHEN 169. 
may have been powerless to prevent it, it regarded the process as contrary to law.

There are a number of reports of interrogation of prisoners under torture during the reign of the Tudors. ${ }^{208}$ Obtaining evidence by torture was a common practice on the Continent in the Late Middle Ages and the Renaissance. The practice had been borrowed from the Roman law during the years following the suppression of the ordeal by the Lateran Council of $1215 .{ }^{209}$ England, however, never seems to have lost her tradition, dating back to the Leges Henrici Primi, ${ }^{210}$ that a confession obtained by threats or force was not good evidence. Fortescue attacks the continental practice of torture vigorously and praises the common law rule. ${ }^{211}$ Thus when torture begins to be used in England, it is not associated with the procedure of any court but rather is an extraordinary proceeding, separated from the regular procedure of any court, which is used in special cases and only at the behest of the King. Though there are a number of reported instances of interrogation under torture during the reign of Elizabeth, the practice never became common nor did it ever receive the color of law. Jardine reports no instances of torture after $1640 . .^{212}$

The year 1640 also marked the death of a more visible and equally notorious institution, the Privy Council's Court of Star Chamber. Apparently established during the reign of Elizabeth, ${ }^{213}$ the Court of Star Chamber was chiefly concerned with political crimes, and has often been identified with questionable investigative techniques. Founded because the regular process of justice seemed too liberal, especially for powerful defendants, the Star Chamber's inquisitorial process was regarded as a much more effective way of finding out the truth than the normal criminal process, and both Bacon ${ }^{214}$ and Coke ${ }^{215}$ regarded the court as a great and noble institution. Its nobility was neither widely nor long appreciated; the history of the court shows that when the power to interrogate is placed in the hands of the state it may be abused by the noblest of judicial bodies. It became the most hated instrument of arbitrary sovereign power and was a principal cause of the Cromwellian Revolution.

208. See generally Lea, Superstition ANd Force 500-08 (1878); Jardine, Readings on the Use of Torture in the Crminnal Law of England (1837); Parry, The History OF TORTURE IN ENGLAND (1933).

209. See LEA, op. cit. supra note 208, at 420-23.

210. Leges, 5, 16(b), LiEberarann, Gesetze der Angelsachsen 550 (1903).

211. Fortescue, CoMmendation of the Laws of England 32-36 (Grigor transl. 1917). See 3 CoKe 35.

212. JARDINE, op. cit. stipra note 208, at 53, 57-58.

213. The Court of Star Chamber should not be confused with the King's Council sitting in the Chamber. See Plucknetr, A Concise History of the Comran Law 17273 (4th ed. 1948). Pollard, Council, Star Chamber and Privy Council under the Tudors, 37 ENG. Hist. REv. 516 (1922).

214. See History of the Reign of King Henry VII, in 6 BACoN, Worrs 85-86 (Spedding ed. 1858).

215. 4 COKE 65. 
A final institution involving the state in criminal investigation during the Tudor period was fashioned from the magistrate's hearing. The magistrate was a judicial officer who had long been part of the system, but whose duties prior to the sixteenth century were ill-defined. ${ }^{216} \mathrm{He}$ seems originally to have been the keeper of the local castle and hence the keeper of the safest place to keep arrested persons until the justices came for Gaol Delivery. ${ }^{217} \mathrm{He}$ is first described in a statute of 1326, 1 Edw. 3, Stat. 2, c. 16, in which he is assigned to "keep the peace" (whence came his title, "justice of the peace"). Later on in Edward's reign, the magistrates were empowered to "take and arrest all those they may find by indictment or suspicion and put them in prison."218 However, corrupt magistrates made a practice of releasing prisoners without formal charge, on the payment of a bribe. Since no records were kept, the justices who came for Gaol Delivery had no way of knowing that a man had been arrested and released. To end these abuses, and as another hesitant step toward introduction of continental practices into English criminal procedure, the statute, $1 \& 2$ Phil. \& M., c. 13 (1554), ${ }^{219}$ was passed. It required that an arrested person be brought before a magistrate to be examined and that the examination be taken down in writing before the prisoner was allowed bail. In addition the magistrate was to examine thoroughly the facts and circumstances of the case, making a written record of the depositions of witnesses against the prisoner. Armed with the arrest power and the power to take depositions, the magistrate began to take a very full part in the investigation of crime; these powers, in addition to his already extensive civil powers, made him the most important local judicial officer. From Stephen's account of the detective work of some of the seventeenth and eighteenth century magistrates, it appears that they did a considerable amount of interrogating. ${ }^{220}$ The interrogation, however, was informal. There are no accounts of a magistrate hauling people off to gaol and questioning them there; rather he seems to have gone out and found his suspects in their own surroundings where he questioned them on the spot. There are few other hints as to how much magisterial interrogation resembled present-day police interrogation.

216. 1 STEPHEN 219-33.

217. Cf. 1 Holdsworth, History of English Law $285-97$ (1922 ed.).

218. Justices of the Peace Act, 1360, 34 Edw. 3, c. 1.

There was apparently great controversy as to just what powers this gave the magistrate. That the magistrate had power to arrest on his own personal suspicion is undenied. The question is whether he could compel others to arrest on his suspicion, issue a warrant or hue and cry. Coke seems to have felt that he could not, 4 Coke 176-77; Hale that he could, 2 Hale, Pleas of the Crown 107-10 (1847). In either case it is clear that the magistrate himself must entertain the suspicion. He could not issue a hue and cry simply at the request of a citizen or of a constable but must inform himself sufficiently of the matter so that he might have reasonable cause to believe that a felony had been committed and that the person to be arrested had committed it. Cf. 1 STEPHEN 191-94.

219. See 1 STEPHEN 218-22.

220. Id. at 223-28. 
The free-wheeling and easily abused power of the magistrate probably would have been curtailed at the end of the seventeenth century in the reforms which purged many of the Roman law accretions of the sixteenth century from English criminal law, were it not for the fact that at about that time state investigation of crime slowed of its own accord. As a result, the older, private techniques of investigation became once more dominant. ${ }^{221}$ It is possible to trace this shift to no particular statute; there seems rather to have been a trend of the times away from the emphasis on public prosecution and on the state's interest in ferreting out and punishing criminals which had marked the seventeenth century. The various methods employed by private parties - involving extensive use of private investigation, private guards, and rewards - are elaborately described by Radzinowicz, ${ }^{222}$ and need not be set out here. While there was no revival of the felony appeal, the citizen nonetheless played an important prosecutorial role. After assembling his evidence, he presented it himself before the grand jury, who heard it and determined whether they would return an indictment. Even when an indictment was returned, the prosecution did not fall entirely in the hands of the state, but the barrister employed to present the state's case was frequently of the complainant's own choosing. Under this private, one might almost say casual, system of law enforcement, the magistrate declined in importance. Under this system judges could achieve a real impartiality between accused and accuser. Since both the complainant and the defendant were private parties and the violation of the rights of the defendant by the complainant's overzealous investigation could always be remedied by a suit in tort, the judges did not feel it necessary to scrutinize the methods by which the evidence was obtained or to regulate the investigation of crime. ${ }^{223}$

In response to a greatly increasing zealousness on the part of the magistrate at the beginning of the nineteenth century, there arose a movement to formalize the magistrate's hearing. ${ }^{224}$ The principal objection to the magistrate's role in the criminal process was that he collected and relied upon evidence without the knowledge of the defendant and collected evidence of which the defendant did not know. Thus the first reform, contained in the Poor Prisoner's Counsel Act of $1836^{225}$ gave the defendants the right to examine at trial a copy of any depositions which the magistrate had taken against them. Twelve years later the magistrate's hearing was subject to sweeping reform by Sir John Jervis' Act. ${ }^{226}$ By that act the accused was permitted to be present at the

221. Id. 418-19, 496-99. See generally 2 Radzinowicz, A Hrstory of English CrimINAL LAW (1956); HowARD, op. cit. supra note 195, at 381-83. In the teeming slums of London, the magistrate still had an important role to play. See note 229 infra and accompanying text.

222. See 2 Radzinowicz, op. cit. stipra note 221, at 33-167.

223. See authorities cited note 221 supra.

224. 1 STEPHEN 228-33.

225. The Trials for Felony Act, 1836, $6 \& 7$ Will. 4, c. 114, 4 .

226. The Indictable Offences Act, 1848, 11 \& 12 Vic., c. 42. 
examination of the witnesses; he was to have the right to cross-examine them, and he was to be allowed counsel. ${ }^{227}$ In addition the accused was permitted to call and examine witnesses in his behalf; he was not required to speak but might make a statement if he so desired. Thus the last inquisitorial element was eliminated from the formal English procedure.

At the same time as Parliament was judicializing the magistrate's proceeding there was developing a new and even more powerful instrument for the state investigation of crime. The story of the origins of the modern police 228 is beyond the scope of this paper. Suffice it to say, in response to the need for police protection unmet by constables or magistrates, a London magistrate, the magistrate of Bow Street, 229 established a force of police, albeit an inadequate one, to guard persons and property and to aid him in investigating crimes. In 1829 Parliament authorized ${ }^{230}$ a police force for the whole metropolitan area of London, on the model of the Bow Street Runners. In 1839 it established ${ }^{231}$ similar forces in all the major cities of the kingdom and in 1856 it required the same for rural areas. ${ }^{232}$

It is hard to say exactly when police interrogation, as we now know it, began. The records of the Bow Street Runners show that they did a certain amount of questioning though it was not nearly so formalized as it is now. ${ }^{233}$ During the bulk of the nineteenth century the courts preserved the fiction of private investigation and treated the police as private persons. There was no formal prosecutor; the police prosecuted personally as did a private prosecutor in the eighteenth century. ${ }^{234}$ The judiciary continued to maintain that there was no need for judicial control of the police since their zealousness could always be controlled by private tort suits. Gradually the investigation of crime became more obviously a public function. During the latter half of the nineteenth century, the police grew independent of the magistracy. In 1879 Parliament provided for the appointment of a Director of Public Prosecutions, ${ }^{235}$ and it became clear that the fiction of private prosecution could be maintained no longer. Correspondingly, checks on state power began once more to appear. In 1912 the English judges adopted the famous Judges' Rules governing police interrogation. These rules, in general, provided that the police could interrogate no accused and that upon arrest they had to

227. The right to counsel is assumed in $\S 17$ of the act and according to Stephen never disputed in practice. 1 STEPHEN 221.

228. See generally 3 Radzinowicz, op. cit. supra note 221 .

229. Id. at 11-63. See generally MAITLAND, op. cit. sitpra note 196, at 105-18; ArMrtage, The History of the Bow Street RunNers (1932); 1 Stephen 196-200.

230. Act for Improving the Police in and near the Metropolis, 1829, 10 Geo. 4, c. 44.

231. An Act for the Establishment of County and District Constables, 1839, 2 \& 3 Vic., c. 93.

232. An Act to render more effectual the Police in Counties and Boroughs, 1856, $19 \& 20$ Vic., c. 69.

233. See, e.g., Armitage, op. cit. supra note 229, at 136-38, 186-87, 235.

234. See 1 StepHen 493-503; MaItLand, op. cit. supra note 196, at 147.

235. Prosecution of Offenses Act, 1879, 42 \& 43 Vic., c. 22. See 1 StEPHEN 501-03. 
warn him that any statement he might make might be used against him.236 Though difficulties with the application of these rules have arisen in more recent times, ${ }^{237}$ the rules represented at the time of their adoption a clear recognition on the part of the judiciary that the criminal process is of one piece - that what goes on in the police station is just as much a part of the criminal process as what goes on at trial, and that the initial confrontation with the state is now in the police station.

Unfortunately there is no Radzinowicz for the history of criminal investigation in the United States, just as there is no Stephen for the history of its criminal law. However, given what is known about the process in the United States, it is safe to assume that criminal investigation took roughly the same form in eighteenth century America as in eighteenth century England. The power of the state was not marshalled against the accused until the trial; there were no police and, though some states seem to have had prosecutors, ${ }^{238}$ private prosecution was the rule rather than the exception. The provisions of the Constitution about criminal procedure support this view of the nature of the eighteenth century process. Of the provisions in our Bill of Rights, only the fourth amendment protection against unreasonable searches and seizures, is directed at the investigative process. Although much constitutional doctrine concerning the police has been hung on this provision recently, historically the Framers seem to have had tax collectors more in mind than the police.239 Since, in the eighteenth century criminal process, the trial marked the critical point of confrontation between the state and the accused - that part of the process in which the defendant's liberty was won or lost - the Framers lavished ten specific provisions on the conduct of trials. The Framers were determined to see that trials were conducted with the utmost fairness, and not according to the standards of the Popish Plot.

American criminal procedure has changed since 1789, just as the English procedure changed. We too have developed vast and powerful forces of police. These police have consolidated the power of the state behind them and have developed the institution of police interrogation. This development has made the modern criminal proceeding essentially different from that of the past; now, the point at which the individual first confronts the amassed power of the state has moved back in the process from trial to the police stage. Ninety per cent of those convicted have pled guilty; they never have had a trial. ${ }^{240}$

236. See Williams, Police Interrogation Privileges and Linitations under Foreign Law: Englaid, 52 J. Crim. L., C. \& P.S. 50 (1960), in Sowle 185-93; DenliN, The Criminal Prosecution in England 31-62 (1958).

237. See Williams, supra note 236, at 50-52, in Sowne at 186-88; Letter from English Policentan on Use of Judges' Rules, in Selected WrItings on the LAW of Evidence aNd Trial 845-46 (Fryer ed. 1957).

238. See Prosecution, in 1 Wickershadr 6-8.

239. See Boyd v. United States, 116 U.S. 616, 624-25 (1886).

240. See note 58 supra and accompanying text. 
In American judicial practice, unlike English, however, this evolution has gone all but unnoticed until very recent times.

In the past, the reaction to the introduction of state techniques like interrogation, established to provide more efficient administration of justice, has been to establish buffers between the machinery of the state and the accused or, where that has been impossible, to destroy the machinery. The abuses to which interrogation by the magistrates and by the Star Chamber gave rise greatly exceeded the advantages in terms of criminals discovered; the Star Chamber was abolished and the magistrate's hearing was surrounded with safeguards. When confrontation with the state occurred at trial, counsel was found necessary because the accused was unable to defend himself.

If the point of confrontation has been pushed back to the police station, how is the individual to be defended there? The course of history strongly suggests that only the most extraordinary individual is capable of standing by himself against the power of the state. It has been argued that since interrogation is a passive process from the defendant's point of view and since the defendant need not put forward a defense during interrogation, all that he needs is someone - a policeman or, perhaps, a magistrate - to inform him of his right to remain silent. Of course, even these protections are not presently assured. And there are situations in which silence is not advisable: the accused may be caught in a web of circumstantial evidence which demands explaining, or it may be prudent for him to make some answer to his accusors in order to avoid the possibility that the courts will regard his silence as an "adoptive admission." 241 In these situations, the accused needs counsel. to help him decide whether it is advisable to speak and what kind of statement to make. In some situations the accused may be able to make a statement in return for a lesser charge ;242 counsel's presence may see to it that this bargain is enforced. More important, officers of the state do not seem the most apt buffers against the power of the state. Even where the accused would not profit by making a statement, he may need counsel in his traditional, protective role.

If counsel were present at interrogation, he could lay open the unknown workings of the process. ${ }^{243}$ Police interrogation is an invisible process, difficult to study. Since the only persons present are the police and the accused, information about the process can come only from the parties involved, both of whom are highly biased. If a man emerges from an interrogation having confessed, he is quite likely to claim that the confession was obtained from him by foul

241. See State v. Sorge, 125 N.J.L. 445, 15 A.2d 776 (1940). But sec People v. Travato, 309 N.Y. 382, 131 N.E.2d 557 (1955) ; State v. Bates, 140 Conn. 326, 99 A.2d 133 (1953).

242. See Newman, Pleading Guilty for Considerations: A Study of Bargain Justict, 46 J. Crim. L., C. \& P.S. 780, 781-88 (1956). Cf. Hale, Theft, LAw and Society 14249 (1952).

243. Cf. Allison, He Needs a Lawyer Now, 42 Ax. Jud. Soc'y 113, 115, 117, 119 (1958). 
means; the police, on the other hand, are likely to claim that no pressure was put on him at all, but that the burden of his guilt weighed so heavily on him that he confessed spontaneously. We are then confronted with the dilemma that we don't know whether counsel is necessary during police interrogation, and we won't know what goes on during interrogation until counsel or some outside element is there.

What attempts have been made to study the ordinary workings of the interrogation process have produced some interesting and possibly relevant results. In 1931, the Wickersham Commission made an elaborate study of the use of the third degree in police interrogation, with reported cases, interviews, newspaper reports, and reports of the Defender organizations as source material. ${ }^{244}$ The Commission came to the conclusion that police brutality and third degree practices were common in many American cities and shockingly prevalent in some. If the materials used were not all reliable, the sheer bulk of them carries weight. In 1961, the President's Civil Rights Commission on the basis of a more limited study, arrived at the same conclusions about present-day police techniques. ${ }^{245}$ In the absence of both reliable evidence and the possibility of collecting such evidence, it is possible to say - at the least - that police brutality has been a common method for obtaining confessions in some places in the past and that there are sufficiently frequent charges of it now to suggest that it is still present if not quite as common today. Counsel's presence at interrogation could serve as a substantial guard against such practices.

Obtaining information about and protecting against brutal practices do not mark the limits of counsel's possible role. The highly charged nature of the situation in which the accused finds himself and the nature of the "ordinary" interrogative methods which the police admit to using are sufficient to give one pause about allowing police interrogation to continue without safeguards. The accused is all alone in the sinister venue of the police station. Taken from his friends and from familiar surroundings by the authority of the state, he is questioned in secret by an officer of the state. The less experienced he is, the more terrifying the circumstances will seem. Any questioning would be "coercive," and the methods used by the police do not make it less so. ${ }^{240}$ Interrogation, the manuals say, ${ }^{247}$ should be conducted in private, in a small, bare room with no windows and with but one door, so that the interrogated person can have nothing to distract him from the persistence of the interrogator. Privacy is essential, since a man will reveal in private what he never would reveal in a group. The interrogator may choose one of two tacks: he may decide to

244. 4 WICKERSHAM 22-24, 152-55.

245. Equal Instice under the Law, in Justice, 5 United States Commission on Civil Rights Reports 16-18 (1961). See generally id. at 5-28, 109.

246. A fine statement of this argument and a review of the police manual material is to be found in Brief for the ACLU as Amicus Curiae, pp. 5-14, Escobedo v. Mllinois, 84 Sup. Ct. 203 (1963).

247. See authorities cited supra note 57 . 
sympathize with the suspect, minimizing the guilt of his crime, and claiming that anyone caught in the same web of circumstances would commit the crime, or he may be hard on the man by claiming that escape and lying are no use, that the police have all the evidence necessary to prove his guilt, or that only a "punk" would act as he has. Numerous tricks are available to get the defendant to talk. The investigator may claim that a co-defendant has talked and flourish a document purporting to be his confession, or the investigators may operate in a team, one of them taking the "hard" approach and the other the "soft" approach. Since these manuals are written by the defenders of the system, we can assume that at least this much coercion is exerted.

The dangers of this system are obvious. The kind of "civilized" interrogation recommended by Inbau and others leaves so much discretion in the police that other, "uncivilized" methods, are likely to follow. Relay questioning can easily lead to all night questioning depriving the victim of food and sleep. The "hard" approach which is to be used on "non-emotional" offenders can, when mistakenly used on "emotional" offenders lead to confessions of nonexistent crimes. There seems but a short step between the "hard" approach and actual threats of violence. The police speak continually of the dangers of organized crime when they seek to have their powers extended; ${ }^{248}$ yet the overwhelming majority of confession cases which have been before the Supreme Court in recent years have involved either private crimes of passion or property crimes committed by sociopaths in the lower economic brackets. 240 Thus there is a strong suspicion that it is only the weak and the first offenders who confess under police pressure while the hardened criminal knows of his right to keep silent and refuses to talk to the police, unless it is to his advantage in striking a "plea bargain." This suspicion is confirmed by the Wickersham Commission's finding that professional criminals are usually not victims of the third degree. ${ }^{250}$ The basic danger with interrogation is that use of it in many cases undercuts a basic premise of our system of justice; we do not feel that a man should be made against his will to condemn himself out of his own mouth. "Ours," as Justice Frankfurter said in Watts v. Indiana, "is an accusatorial as opposed to an inquisitorial system.".251

Interrogation is not only a point of confrontation between the individual and the state, but is also a point of confrontation at which the defendant, especially if inexperienced, is incapable of handling himself. Counsel could serve equally well here as he does at trial as a buffer between the individual and the state. Counsel could: advise the accused of the proper statements to make

248. See authorities cited infra note 253 .

249. For the typical defendant in a confession case see, e.g., Culombe v. Connecticut, 367 U.S. 568 (1961) ; Spano v. New York, 360 U.S. 315 (1959); Ashdown v. Utah, 357 U.S. 426 (1958) ; Fikes v. Alabama, 352 U.S. 191 (1957). See also 4 WICKERSHAMI 15672; Weisberg, Police Interrogation of Arrested Persons, 52 J. CRIMr. L., C. \& P.S. 35-36 (1961), in Sowze at 168-69. But cf. Stein v. New York, 346 U.S. 156 (1953).

250. 4 WICKERSHAMI 156-72.

251. 338 U.S. 49, 54 (1949). "Such has been the characteristic of Anglo-American criminal justice since it freed itself from the practices borrowed by the Star Chamber from the Continent whereby an accused was interrogated in secret for hours on end." 
should the accused wish to make a statement; see to it that the police did not use brutal means to obtain a confession; and assure that the police did not trap the defendant into making a statement against his will, by eliminating much of the inherently coercive atmosphere of the invisible police process. The reason why counsel's presence at interrogation has not heretofore been thought necessary is clear from history. In the past, the gathering of information about crimes was, in the main, a highly informal, private process, which did not confront the accused with the full adversary force of the state until trial; there was no judicial control outside the private remedies of tort. Today, the police process is the point at which the state enters; for ninety per cent of those ultimately convicted of felony, it marks the only point of meaningful confrontation.

\section{The State's Interest in Interrogation}

Yet it is not possible, without more, to thrust counsel into the interrogation process. Proponents of such an extension are always faced with the fervid argument that presence of counsel during interrogation would make interrogation impossible, and, without interrogation, the orderly investigation of crime would be impossible. There is no empirical evidence that the first assertion is true; it is merely argued that counsel would invariably advise his client to keep silent and that all possibility of interrogation would thus be ended.252 Assuming this to be the case, it may yet be doubted that the end of interrogation would result in the collapse of law enforcement or the end of all effective investigation of crime. ${ }^{253}$

In the absence of any thorough study of how many crimes are solved by interrogation, it is difficult either to verify or to refute the statements that interrogation is the only way to solve certain crimes and to obtain clinching evidence in others. Yet there are some indications that the predictions of disaster ought not to be taken at face value. Institutionalized, broad-scale interrogation is a product of the late nineteenth century. In the last 50 years, of course, society may have become so impersonal and vast that interrogation is now necessary; but the development of police interrogation suggests that societal complexity is an inadequate explanation for the growth of this technique. India ${ }^{254}$ and Scotland ${ }^{255}$ have strict rules excluding from evidence infor-

252. Justice Jackson so argues in Watts v. Indiana, 338 U.S. 49, 59 (1949) (concurring opinion). The argument is assumed in Crooker, 357 U.S. at 441.

253. The arguments for the absolute necessity of interrogation may be found in Inbau, Police Interrogation-A Practical Necessity, 52 J. CRIM. L., C. \& P.S. 16 (1961); 1958 Senate Hearings at 2, 123, 124 (statements of Judge Holtzoff, Robert Murray and Edgar Scott); Hearings before Special Subcomnittee to Study Decisions of the Supreme Court of the House Judiciary Committee, 85th Cong., 2d Sess., ser. 12, pt. 1 at 2, 32, 44 (1957) [hereinafter referred to as 1957 House Hearings].

254. Indian Evidence Act $\S 25-26$ (1872). See 2 Chitaley \& Rao, The Indian EVIDENCE Act $\S \S 25-26$ (1956).

255. Chalmers v. H. M. Advocate, [1954] Sess. Cas. 66, has an excellent review of the Scottish law which seems to exclude "the fruit of the poisonous tree" but not "spontaneous" admissions. See Walkge \& Walker, The LaW of Evidence in Scotrand 3741 (1964). 
mation, including confessions, obtained as a result of police interrogation; this practice, which approaches a ban on interrogation, does not seem to have marked effects on those nations' enforcement of their criminal statutes. Nor can substantial detriment be found in the federal and state jurisdictions which operate under the $M c N a b b$-Mallory rule ${ }^{256}$ or an equivalent. If the experience of the F.B.I. can be discounted because their work differs somewhat from that of the average local police force and because they have more substantial resources at their disposal, the District of Columbia and Michigan police ${ }^{267}$ also operate under strict limitations on police interrogation. There is a temptation to think that once a problem has been solved in one way there is no other way to solve it; ${ }^{258}$ yet when existing procedures are foreclosed, new solutions usually emerge. ${ }^{259}$

There is, however, the problem of costs. The price of introducing counsel at the interrogation stage might well prove significant. There would be a considerable alteration of state criminal procedures. Doubtless, the work of the police would become more difficult and time-consuming, as the gathering of physical evidence and the questioning of witnesses grew in importance for the solution of crimes. Given Gideon's apparent requirement that appointed counsel be provided wherever retained counsel is allowed in the criminal process, ${ }^{260}$ the state would also bear the expense of appointed counsel in cases involving the poor. Yet this last expense may not be too great if Gideon also stands for the proposition that the right to appointed counsel must be pushed back to the preliminary hearing. Since the number of people at the police stage of the process seems to be about the same as at preliminary hearing, the expense of introducing counsel one step back to police interrogation will not be as great as it might at first seem. California's experimentation with appointed counsel at preliminary hearing shows that though there is an added cost, it is not so high as to be impractical. ${ }^{261}$

256. See statement of J. Edgar Hoover in Frank, Not GunLTy 185 (1957). See note 69 supra; Civil Rights Commission, op. cit. supra note 245, at 109-10.

257. 359 Mich. 410, 102 N.W.2d 738 (1960).

258. After the Mallory case severely curtailed the use of interrogation by the District of Columbia police, Robert Murray, the Chief of Police of the District, appeared before a subcommittee of the House Judiciary and testified that confessions were necessary for the solution of close to ninety per cent of the crimes in the District. 1957 House Hearings at 43. A year later Oliver Gasch, the U.S. Attorney of the District, stated that fewer than five per cent of the cases in the District had been affected by Mallory. See Weisberg, supra note 249, at 27, 33-34 n.60, in Sowle at 159-60, 167 \& n.60.

259. See Rothblatt \& Rothblatt, Police Interrogation: The Right to Counsel and Prompt Arraignment, 27 Brooklyn L. Rev. 24, 66-68 (1960); Allison, supra note 243, at 116-18.

This view is old. The drafters of the Indian Evidence Act told Sir James Stephen that the reason for interrogation was that, "It is far pleasanter to sit comfortably in the shade rubbing pepper into a poor devil's eyes than to go about in the sun hunting up evidence." 1 STEPHEN 442 n. 1.

260. See note 47 supra and accompanying text.

261. See note 52 supra and accompanying text. 
Another cost to society, which many might find more troubling than added administrative expense, is the fear and losses which must be endured if "criminals" go free. The abolition of interrogation, it is argued, would serve no purpose but to free the guilty, since the innocent never confess. The argument is, first, wrong on its premises ; many innocent people confess to crimes they did not commit. ${ }^{262}$ If the accused is of the type likely to make a compulsive confession, the kind of narrow leading questions the police ask in an interrogation supply him with all the details sufficient to make up a plausible story of crime. Even if only the guilty did confess, moreover, this argument would still have little force. The area of confessions like the area of illegal search is one in which we control the behavior of the police toward the innocent by controlling their behavior toward the guilty. The law of confessions is not that we shall exclude all untrustworthy confessions but that we shall exclude all involuntary confessions. ${ }^{263}$ Many "criminals" escape because illegally seized evidence may not be used at trial, many "criminals" escape because we do not permit torture, and many "criminals" escape because we do not allow hearsay evidence to be admitted at trials. It has never been claimed that ours is the most efficient system of enforcing a criminal law; what is claimed is that the system allows the individual the most freedom compatible with holding society together with a criminal law. We have long since circumscribed the primitive notion of criminality, that all who have committed forbidden acts are guilty, with rules describing the way in which guilt must be found. The criminal process is not simply a fact-finding process but a process for finding facts in a certain way. Guilt that is not sufficiently notorious, so that it must be found from the mouth of the criminal himself or by breaking into his house and seizing his private papers, is not guilt sufficient for the invocation of the criminal process. ${ }^{264}$ Besides, the really grave danger of the professional criminal is in no way mitigated by the institution of police interrogation if only the weak, the psychotic, and the first offenders confess under police pressure, while the hardened criminal knows of his right to keep silent and talks only

262. See N.Y. Post, Mar. 23, 1964, p. 3, cols. 4 \& 5 ("2 Confessions to 1 Slaying: D.A. Asks Why") ; Frank, op. cit. supra note 248, at 165-80 (1957). See also ReIK, The Compulsion to Confess (1959).

263. Broadly summarized by Frankfurter, J. in Culombe v. Connecticut, 367 U.S. 568 (1961).

264. Perhaps Mencken put it best, though cynically, when he said:

Most of us aspire to the majority of those acts [criminal acts] in secret, and some of us commit them surreptitiously, but the marr who performs them in such a manner that the fact becomes notorious is a menace to the security of the rest of us, and we go through the solemn hocus-pocus of seizing him and trying him, and pump up indignation over his rascality and finally visit upon him the thing called punishment.

A Mencken Chrestomathy, in Vorces In Court 540 (Davenport ed. 1958).

For this argument applied to self-incrimination see McNaughton, The Privilege against Self-Incrimination, 51 J. CRIM. L., C. \& P.S. 138, 146 (1960), in SowLE at 223, 232. 
when it is to his advantage. ${ }^{265}$ Then too, the vigor of criminal law enforcement has little demonstrable effect on the amount of crime. ${ }^{206}$ Our system does not strive for one hundred per cent enforcement. As Professor Schwartz has aptly stated:

The paradoxical fact is that arrest, conviction and punishment of every criminal would be a catastrophe. Hardly one of us would escape, for we have all at one time or another committed acts that the law regards as serious offenses ... 100\% law enforcement would not leave enough people at large to build and man the prisons in which the rest of us would reside. ${ }^{267}$

If the criminal process catches a sufficient number of the perpetrators of notorious crimes that the risk of being caught is a substantial one, it has done its job of deterrence.

\section{Striking the Balance - A Iook at Counsel at Interrogation}

The weight of the elements in the balance between the interest of the individual in counsel at interrogation and the interest of the state in interrogation is quite different from what Justice Clark assumed it to be. The right to counsel is not a recent grant of largess by society, bestowed only when society could afford it. Rather, it is one of the oldest of our procedural rights, which was denied by the power-seeking state of the seventeenth century only to return in the eighteenth and to be placed in the Bill of Rights. Counsel does not only serve the function of providing technical aid; he is also a needed buffer at the point of confrontation between the state and the accused, put there because the accused is incapable of defending himself in this moment of stress. When the Bill of Rights was put into effect, its draftsmen recognized that the crucial point of confrontation was at trial. The investigative process, on the other hand, was private; state and accused did not meet until the trial. Now the investigative process is in the hands of the state, and the state and the accused meet during interrogation, in the back room of the police station. If the standards of the Framers are to be enforced in modern times, these standards must be applied at the critical point in the criminal process, no matter where in the process that critical point moves. Interrogation as it is now practiced is a perilous time for the accused, who is defenseless against the abuses of both physical and psychological coercion. Even when there is no intention to make the situation coercive, the questioning of an accused, alone in an alien atmosphere, must be inherently coercive. Counsel, by serving in his traditional role as buffer against the state, could remove the dangers of the situation.

On the other side of the balance is the argument that the presence of counsel will emasculate the process of interrogation and thus cripple or destroy

265. See notes 242,249 supra and accompanying text.

266. See Adenaes, General Prevention-Illusion or Reality?, 42 J. CRIM. L., C. \& P.S. 176 (1952).

267. Schwartz, On Current Proposals to Legalize Wire Tapping, 103 U. PA. L. REv. 157 (1954). 
the enforcement of law. Assuming the predicted end to interrogation, the latter argument, it has been seen, is an overstatement. From the cases on confession there is a strong suspicion that only the weak confess, while the professional criminal is too canny to be trapped. Interrogation has not proved indispensable in the past; and, to a great degree two foreign jurisdictions and two jurisdictions in the United States do without it today. Substantial elements do remain on the state's side of the balance; if counsel makes interrogation impossible, some criminals will probably escape. Secondly, furnishing counsel at this stage would be expensive, if not so expensive as to be completely impractical. Thirdly, the states would have to change their criminal processes. The question is whether these elements are as substantial as they seemed in Crooker in light of our analysis of the right to counsel.

If the balance is established in this way there is no longer the presumption against the extension of the right to counsel. Rather, the burden is on the states to show that there are overriding policy considerations in their favor. The states have come forward only with assertions of the absolute necessity of interrogation, unsupported by any empirical evidence; these may be met with assertions, equally unsupported, that interrogation is not necessary. If the gathering of data concerning police interrogation is at all possible, those engaged in criminal investigation who argue for the necessity of interrogation are presumably the most capable to do it. Similarly state policy makers are most able to gather data on the issue of expense. In the absence of data on either of these topics, the weight of the balance seems clearly on the side of the fundamental right, the right to counsel.

Thus our conclusions favor counsel during interrogation even if the result is the end of interrogation. But the fact that most prosecutors do not now interrogate a man once he has obtained counsel ${ }^{268}$ does not mean that they would find interrogation with counsel useless. Nor does the present practice of criminal lawyers of advising his client to keep silent during interrogation mean that he would invariably advise silence if he were permitted to be present and to have some control over the process. The attorney has not, contrary to generally accepted notions, seen his role as constant impediment to the criminal process, making it as hard for the state as possible. In many cases full disclosure is exchanged for a lesser charge. In fact, more guilty pleas are obtained from counseled defendants than from noncounseled ones. ${ }^{269}$ Furthermore, an attorney may find the flow of information helpful. Counsel now does not invariably advise his client not to take the stand at trial. Similarly, at interrogation, participating counsel may find out what the District Attorney really knows about the case. ${ }^{270}$

268. See Letters from United States Attorneys to the Yale Law Journal April-May 1963, on file Yale Law Library; Note, Reaffirmation of Confessions, 72 Y ALE L.J. 1434, 1454 n.106.

269. See Newman, supra note 242 , at 782, 785-86.

270. See Allison, supra note 243 , at 119 . Cf. Weisberg, supra note 249 , at 44 , in SOWLE at 179. 
Finally, it should be noted that the presence of counsel might result in a number of gains beyond that of protecting the accused against the state. One of the possible effects concerns the role which counsel is to play as a factfinder and as a preparer of the case. It would shock the public to discover that the District Attorney and the police did not begin their investigation of a criminal case until two months after the crime took place, but this is frequently the situation of defense counsel. ${ }^{271} \mathrm{~A}$ requirement that counsel be present during interrogation would put counsel into the picture earlier, making possible a more effective investigation of the crime. Furthermore, reform is only possible if the system of police interrogation is understood. But we can only understand the system if it is made more visible. Reducing the miasma of indefinite rules and doctrine has been a traditional achievement of counsel. He might well clarify the law which presently governs police procedure. Even if counsel did not bring about an immediate clarification of police law, his presence would certainly make it easier for the courts to apply the existing law to police problems by providing a new source of judicial insight into the invisible processes of the police station. ${ }^{272}$

Some may reject entirely the notion of counterbalanced considerations and fall back on the argument that the Bill of Rights simply was not intended to apply to the police stage of the criminal process. The Framers, so the argument runs, viewed the criminal process as having two stages, a fact-finding stage preceding indictment, and a judicial stage beginning with indictment, and they did not intend the Bill to cover the former. ${ }^{273}$ Thus there is an

271. See Beaney, Right to Connsel Before Arraignment, 45 MrNo. L. Rev. 771, 780 (1961) ; Allison, supra note 243, at 119.

272. To the extent that the assurance of safeguards against police brutality would improve the public relations of the police, one of the effects may be that the police will find witnesses more willing to talk to them. See generally Westley, Violcnce and the Police, 59 Am. J. SocroLogy 34 (1953); Weisberg, Police Interrogation of Arrested Persons, in Sowle 153, 170-71.

273. We see the notion applied to the right to counsel in the early New Jersey case of State v. Murphy, 87 N.J.L. 515, 94 Atl. 640 (1915). In that case the defendant urged that his conviction be overruled because he had been persistently denied counsel while he was in the police station after his arrest. The court held that there was no right to counsel at the time of arrest; the sixth amendment does not apply to the states, and even if it did, the amendment commands that a man have "the Assistance of counsel for his defence." In no way, the court held, could what goes on in the police station be regarded as part of a man's defense. See Roberts v. State, 145 Neb. 658, 17 N.W.2d 666 (1945).

This notion has found acceptance in our own day in the concurring opinion of Justice Stewart in Spano v. New York, 360 U.S. 315, 326-27, in which he said that the questioning was illegal because it had been produced by interrogation without counsel after indictment. The thrust of the opinion was that if the interrogation had been before indictment and without counsel it would have been permissible. Prior to People v. Donovan, 13 N.Y.2d 148, 193 N.E.2d 628, 243 N.Y.S.2d 841 (1963), the New York Court of Appeals had pushed the right to counsel back to preliminary hearing, but had not held that there was a right at arrest, the time at which interrogation is most likely. People v. Meyer, 11 N.Y.2d 162, 182 N.E.2d 103 (1960); People v. Waterman, 9 N.Y.2d 561, 175 N.E.2d 
absolute right to counsel at trial based on the sixth amendment, a right only to retained counsel at preliminary hearing based on general notions of due process, and a right to retained counsel during interrogation only if fundamental fairness demands it. This argument depends on a literalistic interpretation of the Bill of Rights-an interpretation which forgets that when the Bill was enacted, the first stage of the process was purely private; the full force of the state did not exist behind it. The words of the sixth amendment are plainly sufficient to support a requirement that counsel be present at all stages in the state's proceeding against an accused. It seems hypocritical to declare that no one is convicted without benefit of the Bill of Rights, if those rights are not available in the back room of the police station where the real determination of guilt or innocence is made.

\section{The Effectuation of the Right to Counsel}

If the conclusions reached above are followed to their logical end, the right to counsel at the police station must be found to be as pervasive as the present right to counsel at trial. To make the right thoroughly effective, the accused must be put in touch with counsel as soon as he is arrested, so that he may have the benefit of counsel's presence and advice throughout the process of confrontation with the state. To insure that counsel is afforded, the accused must be told of his rights at a very early stage by an impartial person, such as a magistrate. Appointed counsel must be available for the poor wherever retained counsel is available for those who can afford him. To prevent police circumvention of the rules, all evidence obtained from the accused by police interrogation, either before counsel enters the case or after he enters but in his absence, would have to be excluded. Of course, once the accused had a lawyer, the police would be free to interrogate him so long as the lawyer was present. Exceptions for spontaneous confessions and for interrogation after an explicit and intelligent waiver of counsel might be allowed by analogy to present exceptions under $M c N a b b$-Mallory and the federal cases on waiver of counsel. Conceivably, other exceptions would be developed. But the system as a whole would provide counsel for every felony defendant soon after his entry into the police process, and the system would be enforced by stringent exclusionary rules.

Political reality and current Supreme Court practice, however, promise that the fruition of this logic, if adopted by the Court, will be long in coming. The problems of effectuating the right were probably crucial in leading the Crooker Court to decide that the right to counsel was not absolute. The placing of counsel at interrogation will involve deep-seated changes in the criminal procedures of the states, changes which the states may not be anxious to make and which are of uncertain expense and effect. It is one thing to find a prior

445, 216 N.Y.S.2d 70 (1961) ; People v. DiBiasi, 7 N.Y.2d 544, 166 N.E.2d 825, 200 N.Y.S.2d 21 (1960). See note 87 sipra.

For the two-stage notion of the criminal process also see Post v. United States, 361 U.S. 583 (1896) ; Counselman v. Hitchcock, 142 U.S. 547 (1891). 
Court mistaken in its assessment of the history and function of counsel; it is another to develop a system for assuring that the accused gets the counsel to which he has a right. Legislatures might-but probably will not-provide for early appointment of counsel by magistrates or make other sweeping changes in the criminal procedures of their jurisdictions. ${ }^{274}$ The Court is presented in Escobedo with only one case-that of an accused accomplice to murder who requested that his retained counsel be permitted to advise him during interrogation; while the Court may engage in expansive dicta, it has compelling reasons to move slowly, making its changes in response to principle, but no faster than its docket requires.

There are two solutions open to the Court in Escobedo. The Court might do no more than declare that there is a constitutional right to counsel in the police station and remand the case to the Illinois courts, leaving for them the problem of effectuation. In $W$ olf $v$. Colorado ${ }^{275}$ the Court held that the fourth amendment right to freedom from search and seizure applied to the states as well as to the federal government, but left the means of enforcing the right to state courts and legislatures. Only after a twelve year period of experimentation, in which it was found that the states adopted the exclusionary rule or failed to respond, did the Supreme Court adopt a uniform means of effectuation. Here the experience might be different. After their experience with Mapp $v$. Ohio, ${ }^{276}$ state courts and legislatures might more readily fashion their own solution to the problem. Permitting state experimentation would blunt reaction to the decision since there would be less of an incursion on state prerogatives.

Yet, the experience under $W e e k s$ and $M c N a b b$-Mallory has shown almost conclusively that solutions other than exclusionary rules are seriously lacking in effectiveness. ${ }^{277}$ The other alternative open to the Court is to recognize

274. See note 277 infra.

275. 338 U.S. 25 (1949).

276. 367 U.S. 643 (1961).

277. Many states, for example, have statutes requiring that the police produce the accused before a magistrate "without unnecessary delay." See 1958 Senate Hearings 735-48 (Maryland is the only state without a statute concerning magistrate's hearing). These statutes do nothing about seeing to it that counsel is present during interrogation. Experience with prompt production statutes also has shown that the base statutory command is not enough to make them obeyed. See Chaffee, Memorandum on the Detention of Arrested Persons and their Production before a Committing Magistrate, in 2 CHAFFEE, Documents in Fundamental. Hunan Rights 502-09 (1951). Several states make it a misdemeanor for a police officer to violate provisions of the arrest law. See, e.g., NEW YoRK PENAL LAW \& 1844 (1955). The problem with these provisions seems to be the prosecutors simply will not enforce them. See Rothblatt \& Rothblatt, supra note 259, at 44: CIVIL RIgHTs Commission, op. cit. supra note 245 , at 79-80. Another way of enforcing laws against the police is by providing those injured with a remedy in tort. Tort remedies, however, are a product of an age in which investigation was a private function and do not seem effective today. The plaintiff has great dificulty in proving damages, and juries seem unwilling to bring in a verdict for plaintiff. Even if he gets a judgment, the plaintiff is likely to find the policeman judgment-proof and the State unwilling to waive immunity. 
this fact and find for itself that the confession was improperly admitted. Under the particular facts of Escobedo, involving a confession obtained after denial of a request for retained counsel, such a holding would not encroach upon vast areas of state terrain. Since a request was involved, the decision would not force upon the states new procedures for apprising an accused of his rights nor threaten the exclusion of evidence obtained before the police had notice that the accused wished to proceed no further. Since retained counsel was involved, the spectre of burgeoning public defender obligations and expenses is not immediately raised. That the evidence sought to be excluded is a confession directly obtained during interrogation makes it unnecessary for the Court to reach the question whether only direct statements must be excluded, as is presently the case under $M c N a b b-M a l l o r y, 278$ or all "fruit of the poisonous tree," as is the case under the Mapp rule.279 Whether the limitations deriving from these distinctions would long remain is conjectural. The "request" rationale not only raises difficult problems of proof, when the police deny that a request for counsel has been made, but also seems to penalize the ignorant who may be most in need of counsel's aid. The retained counselappointed counsel line has been thoroughly discredited by Gideon; the failure

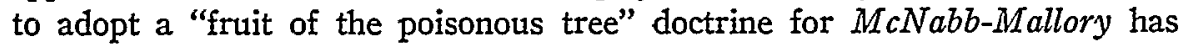
been the major difficulty with that rule, for it has given the police some encouragement to withhold the accused from the commissioner. ${ }^{280}$ The states might well apprehend that change is in the wind. Yet, to the extent that the forecast is uncertain, and that the process of change occurs over a span of time, they would have substantial opportunity to shape their own institutions to accommodate the new insight into counsel's role. ${ }^{281}$

See Crvil Righis Comsisssion, op. cit. sitpra note 245, at 80-82. See generally Foote, Tort Remedies for Police Violations of Individual Rights, 39 MrNw. L. Rev. 493 (1955).

It has been denied that exclusionary rules actually affect police practice, but this statement has been severely challenged as lacking in empirical backing. Compare Waite, Judges and the Crine Burden, 54 MicH. L. Rev. 169 (1955), with Paulsen, The Exchisionary Rule and Misconduct by the Police, 52 J. CrMr. L., C. \& P.S. 255, 262, in Sowle 87, 95. The F.B.I. and the District Police say that they are obeying the exclusionary rules affecting them. See notes 256, 258 sutpra.

278. See Rothblatt \& Rothblatt, supra note 259, at 40-42; compare Goldsmith v. United States, 277 F.2d 335 (D.C. Cir. 1960), with Armpriester v. United States, 256 F.2d 294, 296-97 (4th Cir. 1955) (dictum).

279. See Walder v. United States, 347 U.S. 62, 64-65 (1954); Silverthorne Lumber Co. v. United States, 251 U.S. 385, 392 (1920).

280. See Note, supra note 268 , at 1443 ; note 278 supra.

281. Courts other than the Supreme Court have been experimenting with exclusionary rules designed to effectuate the presence of counsel earlier in the criminal process. The New York courts, for example, have developed a rule which provides that all evidence obtained from interrogation without counsel after indictment or preliminary hearing (called arraignment in New York) is inadmissible. Recently this doctrine has been expanded to include pre-arraignment interrogation from which retained counsel has been excluded. See notes 87, 265 supra. There is some question whether the new New York doctrine applies to the "fruit of the poisonous tree." Judge Van Voorhis in dissent in People v. Donovan, 13 N.Y.2d 148, 161, 193 N.E.2d 628, 635-36, 243 N.Y.S.2d 841, 851-52 
The Court, as well, will benefit by proceeding through a series of cases, each providing a full airing of the considerations relevant to a given issue, rather than by importing the right to counsel whole into the police stage. Such a process characterized the development of right to counsel in judicial proceedings; it seems reasonable to expect that development of right to counsel in the police station will be parallel. The courts will have to deal with the accused who did not ask for counsel in the police station because he did not know of the right, and with the accused who did know of his right but couldn't afford counsel. If provision is made for appointment, the case may arise in which the accused is informed of his right to counsel but is not offered appointed counsel; in another, the accused may be offered counsel but may decline to take the offer so that the question of waiver arises. Defendants could, eventually, pose narrower, administrative issues, that counsel was incompetent, or in league with the prosecutor, or willfully absent at a critical point during the interrogation. Counsel in some cases may have been allowed by the police to advise his client outside the interrogation room but only allowed to be present and silent during the interrogation itself. The hazy distinction between witnesses and those accused might cause difficulties, as it has in England, where the police have a tendency to prolong the period before actual accusation in order to avoid the rigors of the Judges' Rules. ${ }^{282}$ That similar problems have arisen in the trial field does not mean that the solutions to them will be the same in the police field or that the courts and legislatures should automatically transfer all the doctrine of counsel to this new context. A principal ingredient of the present situation is our ignorance of what actually happens during interrogation. Counsel should be able to tell us more of the process. And as counsel observes the process it will change. Whatever solution is reached, the states will have to review their role in the administration of rightto-counsel in the police station.

If appointed counsel is provided, each state will have to decide what kind of institution is best equipped to provide counsel at interrogation in its particular area - public defender, private legal aid, court appointment, or a

(1963), says that it does, but the case he cites for the proposition, People v. Rodriquez, 11 N.Y.2d 279, 222 N.Y.S.2d 353, 183 N.E.2d 651, simply excludes a confession produced by the use of illegally seized articles.

In a recent case in the Fifth Circuit Court of Appeals, Lee v. United States, 322 F.2d 770 (5th Cir. 1963), the court, combining the Crooker doctrine with the old New Yorl: doctrine, held that the trial court should have excluded a confession made after indictment and in the absence of counsel, because the defendant's age and circumstances made it unfair to question him without counsel. By combining the rule of Lee with the $M c N a b b$ Mallory rule the Fifth Circuit has substantially prevented the federal police from interrogating accused persons in the absence of counsel. All that is missing is a recognition that the right to counsel is an absolute both before and after indictment, in addition to a requirement that not only evidence obtained in his absence but products of that evidence be excluded.

282. See authorities cited notes $236-37$ supra. 
mixed public-private organization. ${ }^{283}$ Statutes might govern the scheduling of interrogation; who should perform the interrogating function, when it might be performed, whether a lawyer could seek a stay of the interrogation of his client, or whether he would have to be present regardless of how inconvenient the time.

The legislatures might also consider guiding the process of police interrogation in such a way as to change the institution. They might consider how much criminal discovery should approximate civil discovery. To the extent that an interrogation became more like a deposition, the state might want to consider making mandatory the answering of all but self-incriminating questions. An attorney should be permitted to have access to the courts to prevent interrogations from becoming abusively time-consuming or harassing. On the other hand, the state might consider making criminal investigation less of an adversary process by facilitating joint investigation of crime by defense counsel and prosecutor, a concept towards which the German criminal procedure seems to be heading, ${ }^{284}$ or by introducing judicial interrogation, a procedure used in France. ${ }^{285}$

\section{APPENDIX OF COLONIAL PROVISIONS ON COUNSEL TO 1800}

NEW HAMPSHIRE: There is little on the early courts in New Hampshire. The Constitution of 1776 contains no reference to counsel, though this does not necessarily mean that New Hampshire's courts were not allowing counsel. See Rackow, The Right to Connsel: English and American Precedents, 11 WM. \& MARY Q. 1, 13-14 (3d ser. 1954). The 1784 Constitution contains a provision that in criminal prosecutions, "[E]very subject shall have a right . . . to be fully heard in his defence by himself, and counsel." N.H. Const. pt. I, art. XV (1784), 4 Federal and State Constitutions Colonial. Chatters and Organic Laws 2455 (Thorpe ed. 1909) [hereinafter cited as Thorpe].

VERMONT: The Constitution of 1777 contains provisions similar to New Hampshire's of 1784. VT. Const. ch. I, $\S 10 ; 6$ T HORFE 3741.

MASSACHUSETTS: Early Massachusetts courts frequently ignored the common law; they may have ignored the fact-law distinction though this is not certain: See Rackow, supra at 14. In 1777 Massachusetts passed an act allowing both retained and appointed counsel in trials for treason. 2 Mass. Laws 1049 (1807). The Declaration of Rights in

283. See generally Spectal ComamtTee of the New York Bar to Study Defender Systems, Equal Justice for the Accused (1959); Symposinm Proceedings of the New England Defender Conference, 47 Ans. Jud. Soc'y 159-200 (1964).

284. See Clemens, Police Interrogation: Privileges and Limitations under Foreign Law: Germany, 52 J. CRrMr. L., C. \& P.S. 59; in Sowle at 196.

285. See Vouin, id., France, $52 \mathrm{id}$. at 57, in Sowle at 193; Pound, Legal Interrogation of Persons Accused or Suspected of Crime, 24 J. Crrms. L., C. \& P.S. 1014 (1934). A common law tradition, however, might make the legislatures wary of making interrogation a favored institution, or of emphasizing so much the interest of the state in the interrogation process. 
the Constitution of 1780 contains a provision similar to New Hampshire's. Mass. Const. pt. I, art. 12 (1780) ; 3 THORPE 1891.

RHODE ISLAND: This state seems to have been inimical to the legal profession in general; it may not have allowed counsel beyond the common law provisions. See ReINscr, The English Common Law in the Early American Colonies 29 (1889); 2 Arnold, The History of the State of RHode IsLaNd 78 (1859). In 1666 Rhode Island passed a comprehensive statute governing the conduct of her courts. IAwS AND ACTS of RHODE Island and Providence Plantations 1636-1705, [15]-[18] (Rider ed. 1896). Plate 29 prescribes that after the jury is impaneled "the Partys" shall "have there Lawful Exceptions by themselves or Attorneys who are to plead their Cases." This provision may apply only to civil cases, however, since the specifically criminal section (plate 30) does not mention counsel. On the other hand, the list of fees permissible for an attorney to charge (plate 31 ) prescribes that no attorney may take more than 1s. 8d. for "acquittall of felony or suspicion thereof" or for "acquittall of murder," indicating that attorneys did perform some function in criminal cases. In 1669 this act was clarified by one allowing any indicted person to procure an attorney to plead a point of law because the accused "may be innocent and yett not bee accomplished with soe much wisdome and Knowledge of the law as to plead his own innocencye, \&c." 2 R.I. ColonIal REcords 238-39 (Bartlett ed. 1857). In 1798 Rhode Island passed a statute substantially similar to the sixth amendment of the federal constitution. Declaration of Rights § 6, R.I. REv. PuB. Laws 80-81 (1798).

CONNECTICUT: This state had no statutory provisions similar to its fellow New England states, nor did it pass a constitution around the time of the Revolution. Zepaniah Swift says, however, that the legislature had abolished the English common law of counsel with its facts-law distinction and that the Connecticut courts told defendants of their right to freely assigned counsel in felony cases upon request, and when the defendant could not name counsel, appointed him on their own. 2 SwFT, A SysteMr of tHE LAWS of the State of Connecticut 392, 398-99 (1796).

NEW YORK: The extensive study by Goebel and Naughton of colonial law enforcement in this state seems to show that it followed the seventeenth century common law, though counsel apparently participated fully in informal proceedings like our modern "plea bargaining." Goebel \& NaUghton, Law Enforcement in Colonial New York 573-76 (1944). On the other hand, New York seems to have had a system for appointed counsel in civil cases. Select Cases of the Mayor's Court of New York City 1684 1754, 176-77 (Morris ed. 1935). The constitution of 1777 says ". . . in every trial on impeachment, or indictment for crimes or misdemeanors, the party impeached or indicted shall be allowed counsel, as in civil actions." N.Y. ConsT. art. xxxiv (1777) ; 5 THORPE 2635. Whether this provision means that counsel is to be appointed as in civil actions is hard to tell.

PENNSYLVANIA: The 1682 Frame of Government of this state declared: "[A]11 persons . . . may ... personally plead their own cause themselves, or if unable, by their friend ...." PeNN FraMe of Gov., Laws Agreed upon in England, art. VI (1682); 5 THORPE 3060. This probably granted the medizval right to counsel though it is hard to tell when the word "plead" lost its strictly technical significance and took on the modern meaning of "argue." The 1701 Charter, however, is explicit in its extension of the common law: "[A]11 criminals shall have the same Privileges of Witnesses and Council as their Prosecutors." PenN Charter art. V (1701); 5 Thorpe 3079. In an act in 1718 this right was further explained: "Upon all trials of . . capital crimes . . . learned counsel [shall be] assigned to the prisoners ..." 1 Laws of PeNs. 134 (Dallas ed. 1797). The 1776 Constitution grants the right to a hearing in criminal prosecutions by the defendant and by his counsel. Declaration of Rights, art. IX, PENn. Const. (1776); 5 
THORPE 3083. Granting the right to appointed counsel in all capital cases in the eighteenth century was the equivalent of granting the right in all felony cases.

NEW JERSEY: The Constitution of 1776 contains a provision similar to the Penn Charter of 1701. N.J. CoNST. art. XVI (1776); 5 THORPE 2597. A 1795 statute provides for the appointment of counsel as the defendant shall desire, if he is unable to obtain counsel. LAwS of N.J., 162 (Patterson ed. 1800).

DELAWARE: In this state the Penn Charter of 1701 was in force. 1 THORPE 560; see Rackow, supra at 18. In addition there was a statute in 1719 which had the same provisions requiring the appointment of counsel as the Pennsylvania statute of 1718. 1 DEL. LAws 66 (1797). The 1776 constitution provides that all previous acts shall be in force until specifically repealed. DEL. Const. art. XXIV (1776) ; 1 ThORPE 566: The 1792 constitution includes a right to hearing in every criminal case either by defendant or by counsel and provides that counsel may at seasonable times have access to those in prison. DEI. CoNsT. art. I, §§ 7, 12 (1792); 1 T HORPE 569.

MARYLAND: In Maryland counsel was assigned to civil actions as early as 1721. Proceedings of the Maryeand Court of Appeals 1695-1729, 303 (Bond ed. 1933). The 1776 constitution included a provision requiring simply that the defendant in criminal prosecutions be allowed counsel. MD. Const. art. XIX (1776); 3 THORPE 1688.

VIRGINIA: Scott in his study of colonial criminal law in Virginia declares that the common law of England was in force in this state on the matter of counsel. Scort, Crinimai Iaw in Colonial Virginia 78-79 (1930). There is a statute of 1734 which allows counsel in capital cases upon petition to the court. 4 VA. STArs. 404 (Hening ed. 1820). This provision may simply have been an enactment of the English idea that a man may not have counsel until he is assigned. On the other hand, it may mean that counsel in felonies was always at the discretion of the court though this would oppose the common law principle that counsel in matters of law was a matter of right. Since the common law seems to have been well known in Virginia, this statute probably aimed at giving the courts discretion to assigm counsel for matters of fact. The courts do not seem to have interpreted it so broadly, however. In Virginia slaveowners were permitted to defend slaves who were charged with a felony. $4 i d$. at 128 . Scott adopts the cynical attitude that slaves were too valuable to be hanged without due deliberation. Scorr, op. cit. supra at 78-79. The provision might also represent a revival of the common law notion of the defensor, the lord who appeared as surety for his man.

NORTH CAROLINA: In 1777 North Carolina passed a statute providing that "[E]very person accused of any crime or misdemeanor whatsoever, shall be entitled to counsel in all matters which may be necessary for his defence, as well as to facts as to law ...." 1 N.C. Rev. Laws 225 (Iredell \& Martin ed. 1804).

SOUTH CAROLINA: In 1712 this state enacted the treason statute of $1695,7 \& 8$ Will. 3 , c. 3. S.C. Pub. Laws 25 (Grimké ed. 1790). In 1731 it extended the provisions of this act to all felonies: "[Any person or persons accused of a felony has the right] to advise with counsel thereupon: [the indictment], to make his and their full defence, by council learned in the law. ... And in case any person ... shall desire council, the court ... is hereby authorized and required, immediately upon his or their request, to assign. . . such and so many council not exceeding 2, as the person or persons shall desire, to whom such council shall have free access at all reasonable times." Id. at 129-30.

GEORGIA: In this state the English procedure had been followed since 1754. See Benney, The Rught to Counsel in Amrerican Courts 19 (1955). In the Constitution of 1798 there is a provision that "no person shall be debarred from advocating or defending his cause before any court or tribunal, either by himself or counsel, or both." GA. CoNST. art. III, § 8 (1798); 2 THORPE 799. 